\title{
Influence of Age and Individual Differences on Mouthfeel Perception of Whey Protein-Fortified Products: A Review
}

\author{
Victoria Norton, Stella Lignou and Lisa Methven *(iD \\ Department of Food and Nutritional Sciences, Harry Nursten Building, University of Reading, Whiteknights, \\ Reading RG6 6DZ, UK; v.l.norton@pgr.reading.ac.uk (V.N.); s.lignou@reading.ac.uk (S.L.) \\ * Correspondence: 1.methven@reading.ac.uk; Tel.: +44-(0)118-378-8714
}

Citation: Norton, V.; Lignou, S.; Methven, L. Influence of Age and Individual Differences on Mouthfeel Perception of Whey Protein-Fortified Products: A Review. Foods 2021, 10, 433. https://doi.org/10.3390/ foods10020433

Academic Editor: Laura Laguna Received: 12 December 2020

Accepted: 9 February 2021

Published: 16 February 2021

Publisher's Note: MDPI stays neutral with regard to jurisdictional claims in published maps and institutional affiliations.

Copyright: (c) 2021 by the authors. Licensee MDPI, Basel, Switzerland. This article is an open access article distributed under the terms and conditions of the Creative Commons Attribution (CC BY) license (https:// creativecommons.org/licenses/by/ $4.0 /)$.
Abstract: Protein needs are considered to increase with age, with protein consumption being associated with many positive outcomes. Protein-fortified products are often used to improve nutritional status and prevent age-related muscle mass loss in older adults. Accordingly, older adults are commonly provided with products fortified with whey protein; however, such products can cause mouthdrying, limiting consumption and product enjoyment. Currently, the extent to which age and individual differences (e.g., saliva, oral health, food oral processing) influence the perception of whey protein-derived mouthdrying is relatively unclear. Previous research in this area has mainly focused on investigating mouthdrying, without taking into account individual differences that could influence this perception within the target population. Therefore, the main focus of this review is to provide an overview of the relevant individual differences likely to influence mouthfeel perception (specifically mouthdrying) from whey protein-fortified products, thereby enabling the future design of such products to incorporate better the needs of older adults and improve their nutritional status. This review concludes that age and individual differences are likely to influence mouthdrying sensations from whey protein-fortified products. Future research should focus more on the target population and individual differences to maximise the benefits from whey protein fortification.

Keywords: older adults; individual differences; whey protein; mouthdrying; protein-fortified products

\section{Introduction to Malnutrition in Older Adults}

In recent decades, there has been a worldwide increase in ageing populations and in 2019, globally, there were 703 million individuals aged 65 years or over; this is predicted to increase to 1.5 billion by 2050 [1]. Older adults are typically described as people aged 65 years or over [1,2], and within this review, older adults will be referred to as individuals aged 65 years or over. However, this description reflects a broad range of individuals with differing needs and abilities. Ageing can be described simply as getting older and more specifically, from a biological viewpoint, as the accumulation of molecular and cellular damage over a lifespan contributing to a decline in function and increased disease risk [3]. The health needs of an ageing population can, however, be described as complex and associated with physiological changes, disease and multimorbidity [3]. The World Health Organisation (WHO) have used the term 'healthy ageing' to promote functional ability within an ageing population and more recently introduced 2020-2030 as the 'Decade of Healthy Ageing' to provide a focus on improving the lives of older adults [4]. In addition, simple health behaviours, such as good nutrition and physical activity, can provide health and well-being benefits, as well as promoting longevity [3].

Good nutrition is associated with numerous positive benefits, such as improved health and well-being. Energy, protein, vitamin C, vitamin D, folate, iron, zinc and fibre are considered important nutrients for older adults [5]. Energy requirements are considered to decline with age due to body composition changes and reduced physical activity [6]. However, protein needs are considered to increase with age (as outlined in Section 2), but, as 
with most other nutrients, recommendations typically remain the same as those suggested for adults generally [7-9] (for a recent review on nutritional recommendations in older adults see Dorrington et al. [10]). Additionally, there are adverse effects associated with the ageing process, which is considered to be a multidimensional process, including physical, psychological and social changes, all of which are potential risk factors for malnutrition (Table 1) [11].

Table 1. Suggested risk factors for malnutrition (adapted from [12-14]).

\begin{tabular}{|c|c|c|c|}
\hline Social & Physical & Medical & Psychological \\
\hline $\begin{array}{l}\text { Living and eating } \\
\text { alone }\end{array}$ & Physical disabilities & $\begin{array}{l}\text { Swallowing } \\
\text { difficulties } \\
\text { (dysphagia) }\end{array}$ & Anxiety \\
\hline Poverty & Reduced appetite & Eating disorders & Depression \\
\hline $\begin{array}{l}\text { Difficulty in shopping } \\
\text { or preparing food }\end{array}$ & Poor dentition & Medication & Dementia \\
\hline $\begin{array}{l}\text { Limited nutrition } \\
\text { knowledge and } \\
\text { cooking skills }\end{array}$ & & $\begin{array}{l}\text { Conditions leading to } \\
\text { reduced appetite and } \\
\text { absorp- } \\
\text { tion/utilisation of } \\
\text { nutrients }\end{array}$ & Bereavement \\
\hline
\end{tabular}

Varying definitions of malnutrition are reported within the literature [15]. One of the most commonly used describes malnutrition as a "deficiency or excess (or imbalance) of energy, protein and other nutrients" resulting in negative consequences "on tissue/body form (body shape, size and composition) and function and clinical outcome" [13]. Typically, the focus within older adults is largely on undernutrition (a deficiency in both macronutrients and micronutrients) $[13,16]$. Malnutrition is prevalent amongst older adults with increased risks associated with age, gender (female), disease status and clinical settings (hospitals, care homes and mental health units) [13,17]. Twenty-three percent of European older adults are considered at risk of malnutrition and over one million older adults are affected in the UK $[13,17]$. Malnutrition is commonly linked with reduced functional status, muscle function, bone mass and cognitive function, poor wound healing, delayed recovery from surgery, mortality and higher hospital readmission rates [11]. A five-step screening process 'Malnutrition Universal Screening Tool' (MUST) is regularly used in the UK to categorise patients for risk of malnutrition in a range of clinical settings [18]. Typically, an individual can be described as 'malnourished' if they have a body mass index (BMI) lower than $18.5 \mathrm{~kg} / \mathrm{m}^{2}$ or an unplanned weight loss ( $>10 \%$ within the last $3-6$ months) or a combination of a BMI lower than $20 \mathrm{~kg} / \mathrm{m}^{2}$ and an unplanned weight loss (>5\% within the last 3-6 months) [19].

Malnutrition can contribute to sarcopenia, which is an age-related loss of skeletal muscle mass and function that is exacerbated by low protein intake alongside poor conversion of protein to muscle mass [20]. Sarcopenia has been reported to affect $5-13 \%$ of adults in their sixties and $11-50 \%$ of those in their eighties [21]. Despite it being considered a preventable and treatable condition, it is a contributor to increasing health costs; muscle weakness conditions in the UK cost $£ 2.5$ billion per annum [20,22]. Sarcopenia has been identified as a potential precursor to frailty, both conditions being multi-dimensional, reversible and with inflammatory links [23]. Frailty can lead to reduced strength, endurance and physiological function, thereby increasing vulnerability to external stressors [24].

Reduced appetite can lead to increased risk of malnutrition in older adults. Factors such as loss of smell, oral and taste impairments, medication, anorexia of ageing, physiological, psychological and social factors can all contribute to a decline in appetite [25-29]. Additionally, this decline is considered to result partially from delayed gastric emptying (increased time food spends in the stomach), thereby increasing satiation and reducing appetite [30]. The type of foods (liquid or solid) consumed can influence food intake. For example, in a study involving healthy older adults consuming a liquid beverage resulted 
in increased subsequent intake (13.4\% increase in oatmeal) compared with a solid energy bar [31]. Furthermore, the texture of foods (such as chewy, hard and viscous) influence appetite regulation, where increased processing within the mouth has been shown to lead to increased feelings of satiety [32]. A meta-analysis by Giezenaar et al. highlighted reduction in energy intake, hunger and increased fullness were all associated with age [33], therefore, promoting foods that encourage food intake is key to counterbalancing this.

Poor oral health can have a detrimental impact on an individual's nutritional status, health and well-being [34]. Oral impairments can impact biting, chewing and swallowing of foods [35]. Older adults typically suffer from teeth loss, dental caries, reduced saliva flow, changes in oral mucous membrane and chewing efficiency, mouth dryness and increased periodontal diseases and use of dentures, all likely to influence food habits and intake [34]. For example, data from the UK National Diet and Nutrition Survey 2008-2014 identified that dental status impacted food selection, and nutrient intake in older adults with compromised dental status (such as edentate and/or dentate with denture wearers) had a negative effect on intake [36]. Kremer et al. demonstrated that older adults, who were denture wearers, perceived custards to be less creamy and less easy to swallow compared with those with natural teeth [37]. Dentures can result in changes in mouth movements, chewing efficiency and sensory thresholds $[35,37,38]$. Saliva lubrication can influence comfort of wearing dentures [35] and decline in oral health can also contribute to taste disorders within older adults [39]. For example, poor oral hygiene, dry mouth, caries and high growth of oral bacteria have been shown to decrease taste ability in acutely hospitalised older adults (70-103 years) [40]. Therefore, maintaining good oral health can increase appetite, food intake and improve taste perception [40]. The impact of medication must also be considered when investigating nutritional status and age. A recent Health Survey for England (2016) identified that whereas only 19\% of young adults (16-24 years) used at least one prescription medication per week, this increased to $80 \%$ of older adults (65-74 years) and was $96 \%$ for those over 85 years [41]. Medication commonly has side effects such as affecting oral health, appetite and taste $[29,42]$, thereby contributing to an increased risk of poor nutritional status.

Nutritional support can provide a cost-effective treatment to improve functional and clinical outcomes for individuals at risk of malnutrition [43]. Accordingly, the British Dietetic Association (BDA) promotes a food first approach to enhance nutritional intake; recommended strategies are outlined in Figure 1 [12].

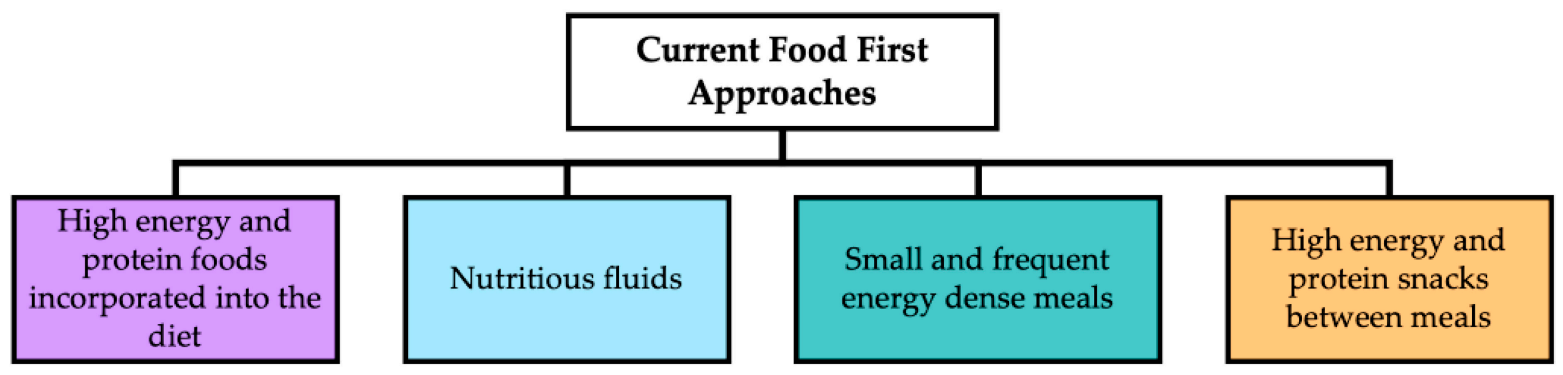

Figure 1. Commonly used strategies to improve nutritional intake in older adults at risk of malnutrition (adapted from [12]).

In summary, the health and nutritional needs of an ageing population are considered complex and involve numerous age-related changes, which subsequently influence food intake and quality of life, all contributory factors to poor nutritional status amongst older adults. Protein-fortified products provide a key role in promoting a food-first approach to enhance nutritional intake and support the recognised increased protein needs with age. Such products often contain animal-derived proteins, for example whey proteins, which are considered complete sources of protein (including all essential amino acids), whereas plant-derived proteins are typically incomplete sources of protein (lacking one or two essential amino acids) [44]. Furthermore, animal-derived proteins are more readily 
digestible and effective in muscle protein synthesis than plant-derived proteins [44]. It is, therefore, important that whey protein-fortified products have consumer acceptance, which relies on a good sensory profile. However, recent reviews $[45,46]$ have shown such products are associated with astringency or mouthdrying attributes. To date, such reviews have not considered the additional dimension of individual differences within the target population. Establishing the impact that age and individual differences may have on whey protein perception would have particular relevance for older adults so as to mitigate characteristics linked to poor consumer acceptance. Accordingly, the main aims of this review are to summarise the latest research relating to (a) protein-fortified products for older adults; (b) exploration of the mechanisms underpinning whey protein-derived mouthdrying; (c) the influence that age and individual differences could have on the perception of whey protein-derived mouthdrying, as well as providing suggestions for future research.

\section{Protein Requirements and the Importance of Protein-Fortified Products in the Diet of Older Adults}

Proteins are polymers of amino acids and provide key roles in tissue growth and repair [47]. The 'Protein for Life' research team has recently identified that many individuals within the UK have inadequate protein intake to maintain muscle strength and function in older age [22]. In addition, an improvement in protein intake during the life course could potentially reduce the onset of certain health conditions and also slow the rate of muscle decline [48]. The 'Protein for Life' focus groups, which involved healthy adults, also identified a lack of certainty over optimal protein intakes during the life course [22]. The UK current reference nutrient intake (RNI) for adults is $0.75 \mathrm{~g} / \mathrm{kg} / \mathrm{d}$ [47], yet protein needs are considered to increase with age. For example, recently, the PROT-AGE study group and the European Society for Clinical Nutrition and Metabolism (ESPEN) expert group have both reviewed protein intake in the older population $[7,8]$. Both studies have recommended a protein intake of $1.0-1.2 \mathrm{~g} / \mathrm{kg} / \mathrm{d}$ for older adults and higher protein intakes $(1.2-1.5 \mathrm{~g} / \mathrm{kg} / \mathrm{d})$ for older adults suffering from acute and chronic disease [7,8]. These findings are also supported by recent BDA and Parenteral and Enteral Nutritional Group (PENG) guidelines for nutritionally vulnerable adults in clinical settings, which recommended protein intake of $1.1 \mathrm{~g} / \mathrm{kg} / \mathrm{d}[12,49]$. These increased protein intakes are considered necessary to maintain good health, encourage recovery from illness and preserve functionality as a result of agerelated changes in protein metabolism [7]. In addition, factors such as sarcopenia, anabolic resistance, disease related protein catabolism, low postprandial amino acid availability and decreased muscle perfusion can also result in increased protein needs for an older adult [8]. The ESPEN Expert Group identified various possible causes for reduced protein intake in older adults, including socioeconomic status, medical conditions, physiological changes, genetic predisposition and physical disability [8].

Protein is considered a satiating macronutrient which can lead to reduced intake at subsequent meals compared with fat and carbohydrates [50]. The proposed mechanisms include increased diet induced energy expenditure, satiety hormones and amino acids, as well as modulation of gluconeogenesis [50]. However, such studies have generally been in younger adults and the response may be modulated by age [51,52]. For example, in two studies by Giezenaar et al. whey protein drinks were not found to be satiating in older adults compared with younger adults [51,52]. They identified older male volunteers showing an increase in appetite, slower gastric emptying and increased overall energy intake [51]. However, appetite decreased following consumption of whey protein drinks in younger male volunteers [51]. Additionally, with older male and female volunteers, ad libitum energy intake was not affected $3 \mathrm{~h}$ post whey protein drink consumption [52]. Appetite is considered to decrease with age per se, and these findings provide support for protein supplementation as an effective nutritional intervention to increase protein intake.

In order to enhance nutritional intake in older adults, a product needs to be palatable, appetising, of suitable portion size and energy dense [30]. Typically, oral nutritional supplements (ONS) and protein-fortified products are used to improve protein intake in older adults. ONS are commonly consumed by older adults and those at risk of malnu- 
trition, where they are unable to meet nutritional needs from their diet [53]. They consist of products which provide macro and micronutrients in semi-solid, powder or liquid form [53]. Protein powders have varied applications and uses within food processing [54] and many high energy drinks contain whey protein (further outlined in Section 3) due to its high nutritional and functional values [51,55] often as whey protein isolate (WPI) or whey protein concentrate (WPC) [56]. Protein-fortified meals and snacks can provide a simple alternative to ONS and provide familiar foods to older adults which can encourage consumption by increasing energy and protein intake $[57,58]$. Variety is required to avoid taste fatigue and improve compliance and intake amongst older adults, including different flavours, textures and appearance [30].

Multiple studies have demonstrated benefits from protein supplementation and/or protein fortification. For example, Cawood et al. carried out a systematic review of 36 studies highlighting benefits of high protein ONS (20-54\% energy from protein) and concluded there was a $19 \%$ reduction in complications (healing of surgical wounds, pressure ulcers and infections rates) following consumption across various settings (hospital and community settings) [59]. A recent randomised control trial was carried out with 104 malnourished care-home residents comparing ONS outcomes $(n=53)$ with dietary advice $(n=51)$ for 12 weeks [60]. The ONS had energy density between $1.3-4.5 \mathrm{kcal} / \mathrm{mL}$ with voluntary intake measured against a target of $600 \mathrm{kcal}$ and $16 \mathrm{~g}$ protein per day [60]. This study supported that nutritional intake and quality of life were significantly improved in the ONS group compared with the conventional dietary advice group [60]. Bauer et al. demonstrated a significant improvement in muscle mass following a three-month period of ONS consumption, containing vitamin D and leucine-enriched whey protein, compared with the control group, amongst older adults with sarcopenia [61].

Food fortification using familiar foods could also be considered as a viable route to increase protein intake within an ageing population. A study involving a hospital setting compared the provision of protein-fortified meals ( 23 dishes fortified with milk protein 6.1 to $11.5 \mathrm{~g}$ of protein per dish; breakfast, soups, fish, meat, side dishes and desserts) with the standard hospital menu (3 main meals with 2-3 in-between meals) [62]. The fortified food service resulted in significant improvement in protein intake amongst patients at nutritional risk [62]. Appleton and Smith noted that using improved visual cues, recognisable foods and/or identification labels can enhance liking for flavours of drinks in older adults [63]. Beelen et al. carried out a pilot study using familiar products (bread, soups, fruit juices and instant mashed potato) enriched with 5.6 to $10 \mathrm{~g}$ protein (dairy and soy) per portion [64]. This pilot study highlighted the benefits of such products in increasing protein intake within an older population $(n=22)$ in a clinical setting [64]. The same research group carried out a subsequent randomised controlled trial using similar protein enriched familiar products (bread, cakes, soups, porridge, meat, mashed potatoes, ice cream, fruit juice and dairy products; protein content per portion varying from 5.8 to $21.6 \mathrm{~g}$ ) [65]. They demonstrated an increase in protein intake over a 12 -week period in older adults $(n=75)$, resulting in $72 \%$ of the individuals meeting the recommended intake of $1.2 \mathrm{~g} / \mathrm{kg} / \mathrm{d}$, whereas only $31 \%$ of those in the control group met those recommendations [65].

Negative outcomes have been associated with a high protein intake. For example, its effects on kidney function, though a recent meta-analysis demonstrated that in healthy adults this was not the case [66]. Similarly, it has also been suggested it could have a negative outcome on the gut microbiota. However, a recent randomised control trial in older men demonstrated that despite consuming $1.6 \mathrm{~g} / \mathrm{kg} / \mathrm{d}$ for 10 weeks, the gut microbiota composition and microbiota derived volatile organic compounds production remained unaltered [67]. In addition, Stratton and Elia [68] noted that minimal gastrointestinal symptoms (such as nausea, bloating and diarrhoea) could arise from ONS consumption; however, they also highlighted that there are limited studies which evaluate fully gastrointestinal tolerance. Moreover, such side effects from protein supplementation typically result from the non-protein components (e.g., lactose intolerance) [69]. 
In summary, protein needs are considered to increase with age, with increased protein intake associated with many positive functional outcomes. Hence, ONS and proteinfortified products prove beneficial to nutritional status.

\section{The Use of Whey Protein to Fortify Foods for Older Adults}

Bovine milk is commonly incorporated into human diets with its associated nutritional and functional benefits [70]. Milk typically comprises water, lipids, lactose (sugar) and protein, as well as minor components (such as minerals (notably calcium), vitamins (both water- and fat-soluble vitamins), hormones, enzymes and miscellaneous compounds) [71]. Milk protein mainly derives from casein (phosphoproteins; $80 \%$ of milk proteins and insoluble at $\mathrm{pH} 4.6$ ) and whey (globular proteins; $20 \%$ of milk proteins and soluble at $\mathrm{pH}$ 4.6), as well as proteinaceous materials (proteose peptone (PPs) and non-protein nitrogen $(\mathrm{NPN}))[71,72]$. Whey is a by-product of cheese making; it is the liquid remaining once the milk has been coagulated (curdled) [73]. Liquid whey can be dried to produce different whey powders (see Bansal and Bhandari [73] for an extensive overview). In summary, WPI (>90\% protein) is typically subjected to further processing compared with WPC (34-89\% protein), resulting in its higher protein concentration and lower fat, ash (mineral) and lactose content $[44,55]$. Demineralised whey powder is a reduced minerals whey powder, associated with reduced corresponding tastes such as salty and bitter [73]. Whey permeate is a by-product of whey production and is a deproteinised whey powder comprising predominantly of lactose and minerals [74].

Whey proteins consist of $\beta$-lactoglobulin, $\alpha$-lactalbumin, glycomacropeptide, bovine serum albumin (BSA), immunoglobulins, lactoferrin and lactoperoxidase in varying amounts, as summarised in Figure $2[75,76]$. Whey proteins provide a source of essential amino acids (EAAs) and branched chain amino acids (BCAAs; leucine, isoleucine and valine) [44]. In addition, whey protein is a rapidly digestible protein that is considered to provide greater nutritional benefits to older adults compared with other protein sources (such as casein), which leads to its frequent use in clinical nutritional products $[77,78]$. For example, the benefits of whey protein have been identified in an acute study with an older male population where postprandial muscle protein accretion was found to be more effectively stimulated by whey protein, compared with casein and casein hydrolysate [79]. Whey protein ingestion can result in an improved muscle protein synthetic response, which is considered to be due to its higher leucine content and quicker digestion and absorption kinetics compared with other protein sources [79]. Review papers have identified a number of additional potential health benefits associated with whey protein consumption, such as its antimicrobial, antiviral and anticarcinogenic effects, as well as improved immune, bone and cardiovascular health [72,80].

In order for ONS and protein-fortified products to lead to beneficial nutritional and health outcomes, enough product should be consumed to meet an individual's daily nutritional requirements. However, compliance is reported to be variable, reducing the nutritional impact, in addition to cost and waste implications [81]. For example, a systematic review from 46 studies identified ONS compliance levels varying between $37 \%$ and 100\% (with average compliance at 78\%) within different settings (hospital setting: 67\% and community setting: 81\%) [82].

Whey protein-fortified products typically have poor consumer acceptance and this has been linked to both undesirable taste and aroma attributes, as well as negative mouthfeel attributes, such as a build-up of mouthdrying, mouthcoating, chalky, metallic and filming, associated with repeated consumption [81,83-88]. Mouthdrying has been perceived by consumers in two different whey protein-fortified food matrices [89,90]. For example, within a liquid model, beverages fortified with whey protein were associated with mouthdrying, low liking scores and presence of off flavours $[83,89,91,92]$. Within a solid model, snacks (such as cakes, muffins, biscuits and rye bread) fortified with whey protein were perceived as mouthdrying and/or had a dry texture and reduced liking $[90,93,94]$. These studies demonstrate consumers can perceive negative sensory attributes associated with whey 
protein-fortified products and mitigating such attributes may be the key to promoting compliance and suitability for older adults.

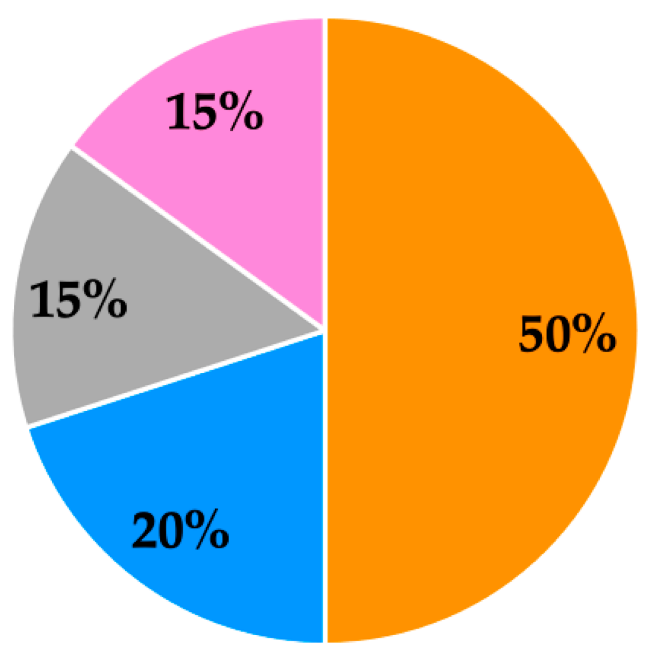

Figure 2. Overview of whey protein typical percentage composition [76] (minor components of whey protein are bovine serum albumin (BSA), immunoglobulins, lactoferrin and lactoperoxidase).

The sensory profile (measured using trained sensory panels) of whey proteins typically includes attributes such as aroma intensity, sweet aromatic, musty, cooked/milky, doughy/fatty (described as "aroma associated with canned biscuit dough"), metallic, cucumber, cabbage, brothy, cardboard/wet paper, animal/wet dog, pasta water, soapy, faecal, catty, grainy, opacity, bitter, astringent, chalky, thick, mouthdrying, mouthcoating, furring and body [86,95-98]. WPI and WPC are considered to have relatively similar sensory profiles (despite processing differences), with the following key differences: WPI has been shown to elicit attributes such as soapy, animal/wet dog, cucumber and bitter, which are typically not present in WPC, whereas WPC has attributes such as sweet aromatic and cooked/milky, which are not present in WPI [95].

Whey proteins are commonly fortified into a range of food matrices, with differing effects on the sensory profile. For example, trained sensory panels identified mouthfeel attributes such as chalky, drying, mouthcoating, astringency, furring and body following whey protein beverage (WPB) consumption and heat treatment of WPB is considered to intensify further these sensory properties [86]. The addition of WPI to sauces has been found to contribute additional flavour attributes (fishy, vegetable soup, chemical, savoury, bitter) as well as mouthfeel (grainy) [99]. Similarly, fortification of biscuits with WPI has been shown to alter appearance (roughness, density), flavour (bitter, savoury, burnt sugar, off flavours) and mouthfeel (teeth packing and slower melt rate) $[90,100]$. Cakes have also been fortified with WPI and WPC, which led to an increase in negative attributes such as mouthdrying, chewy, increased crumb size and firmness of bite [90].

In summary, whey protein fortification is a commonly used to help prevent agerelated muscle mass losses. However, negative sensory attributes leading to poor consumer acceptance and compliance are commonly associated with ONS and protein-fortified products. Whey proteins are frequently cited as being a source of mouthdrying in a range of different whey protein-fortified food matrices. We consider that this needs further investigation, given that older adults are noted to suffer commonly from dry mouth or reduced saliva flow [101,102].

\section{Mouthfeel and Mouthdrying Perception of Whey Protein-Fortified Products}

Texture is considered a dynamic process as foods are continuously being manipulated within the mouth [103] and is more specifically defined as "the sensory and functional manifestation of the structural, mechanical and surface properties of foods detected through 
the sense of vision, hearing, touch and kinesthetics" [104]. Szczesniak and Kahn proposed consumers' awareness of texture is increased if expectations are not met, therefore suggesting texture provides a key role in food preference [105]. Szczesniak described texture as a 'sensory property' and is considered best described and perceived by humans mainly via touch and pressure senses within the mouth during food evaluation [104]. Mouthfeel can be described as "the tactile (feel) properties perceived from the time at which solid, semi-solid or liquid foods or beverages are placed in the mouth until they are swallowed" [103].

Astringency, oral drying and mouthdrying are commonly used terms (and are often used interchangeably) to describe this considered 'textural defect' associated with dairy products [106]. The term astringency has been defined as "the complex of sensations due to shrinking, drawing or puckering of the epithelium as a result of exposure to substances such as alums or tannins" [107]. Such a perceived texture change within the oral cavity usually results from the consumption of plant-derived products rich in polyphenols, such as tea, wine, nuts and fruit $[108,109]$. As highlighted in recent reviews, astringency is considered a 'complex sensation' and potentially derived from multiple mechanisms and often builds and persists post consumption $[45,110,111]$. Plant-derived protein beverages (fortified with pea and soy protein) have been shown to impart astringency sensations; however, this is proposed to result from their polyphenol content rather than as a direct result of the protein composition $[98,112,113]$. Polyphenols are considered to interact with salivary proteins causing aggregation and precipitation, thereby reducing lubrication of saliva, increasing friction and potentially exposing mechanoreceptors, resulting in an astringent sensation $[110,114-116]$. However, as polyphenolic compounds are not present in whey protein sources, the term mouthdrying (a drying sensation in the mouth during or after consumption of a product) is considered more suitable in the context of dairy products. Accordingly, this review uses the term mouthdrying to describe whey proteinderived mouthdrying. However, astringency related oral drying from food models has been researched widely (see reviews $[45,110,111]$ ) compared with whey protein-derived mouthdrying and could, therefore, provide suggestions in terms of mechanisms, mitigating strategies and testing methods.

A recent review by Pires et al. highlighted factors such as $\mathrm{pH}$, temperature, saliva, viscosity and polysaccharides as being likely to influence astringency perception [45]. Furthermore, the detection thresholds for individuals vary for astringent stimuli, which are perhaps influenced by differences in the number of receptors $[111,117,118]$. This has been related to indirect markers (such as 6-n-propylthiouracil (PROP status) and fungiform papillae density), as well as to direct measures of variation in oral tactile sensitivity and saliva flow $[111,117,118]$. A link has also been proposed between individual salivary protein content (pre- and post-stimulation) and astringency ratings in liquid food models (juices with added tannic acid and aqueous solutions with tannic acid and alum). Individuals grouped as 'high responders' (showing reduced replenishment of salivary proteins) perceived astringency as more intense $[119,120]$. However, in a solid chocolate model, differences in salivary protein were not related to perception of astringency [120]. The high fat level in the chocolate may have increased lubricity, which perhaps negated the effect of differences in salivary protein content on the perception of astringency [120].

Understanding oral movements, and where in the oral cavity volunteers perceive drying sensations, could also provide useful insights. Breslin et al. proposed astringency sensations could occur from altered and increased mechanoreceptor activity and demonstrated astringency perception was more apparent with oral movements [109]. A lack of tongue movements minimised perceived astringency in one study, suggesting astringency perception requires at least some oral movement [121]. Astringency can also be perceived on the upper lip and gum [109], suggesting a whole mouth approach is best to understand perceived astringency sensations. A key limitation within this area is the inability to measure astringency effectively. Currently, no method has been developed to achieve this, though typically, a combined approach of direct and indirect methods is used, as highlighted in a recent review [45]. 


\subsection{Whey Protein-Derived Mouthdrying}

Consuming dairy products can also result in a perceived texture change within the oral cavity similar to that with plant-derived products [108]. More specially, whey proteins have been shown to be a source of mouthdrying in fortified products and ONS; hence, addressing the potential causes of whey protein-derived mouthdrying is a key priority [122]. Proposed causes are summarised in Table 2. Initial research suggested that the low $\mathrm{pH}$ associated with some WPBs can cause mouthdrying due to protein precipitation in the mouth and subsequent saliva protein interactions [123-127]. The resulting mouthdrying could be related to increased particle size and turbidity [124,126]. Particle size also increases with heating time [86] and elicits a mouthdrying response at a neutral $\mathrm{pH}$ WPB $[86,122]$. Mouthdrying could also be influenced by disruption of the salivary structure causing reduced lubrication from saliva and resulting in increased friction and perceived mouthdrying [128]. There is evidence that whey proteins, a natural polymer, demonstrate tissue adhesion [129] and mucoadhesion properties [130]. For example, a previous in vitro study has shown that, despite being washed with artificial saliva, proteins remained on the buccal mucosa or tongue apex (with proteins bound to the oral mucosa) [131]. Indeed, more recently, our research group confirmed in a human oral retention study that protein does adhere to the oral cavity post WPB consumption to a greater extent [89]. Although whey proteins have a high nutritional value, they become unstable when heated, resulting in protein denaturation and aggregation, which influences the structure and stability of the protein [132]. Heat treatment of whey proteins can result in increased mouthdrying [86,133] and Bull et al. demonstrated increased oral retention of whey protein following a heated WPB compared with an unheated WPB, therefore suggesting oral retention could have a role in mouthdrying [134]. The increased mucoadhesion strength associated with whey protein denaturation is considered to derive from interactions associated with hydrogen bonding and disulphide bridges [130]. Furthermore, a recent review [135] investigated interactions between saliva and food proteins (focusing both on whey proteins and non-whey proteins) and suggested electrostatic interactions between positively charged food proteins and negatively charged regions of mucin as a likely mechanism. However, as noted above, there could be other relevant mechanisms involved, as proteins (including $\beta$-lactoglobulin) would remain positively charged at the neutral $\mathrm{pH}$ within the oral cavity [131]. More broadly, Celebioglu et al. concluded that both hydrophobic and hydrophilic interactions may be responsible for mucin interactions with various types of food protein in varied food matrix conditions (e.g., $\mathrm{pH}$ dependency) [135].

The investigation of these potential causes of whey protein-derived mouthdrying requires appropriate methods and ideally should be tested within the target popula-tion. Currently, the majority of the literature, as outlined in Table $3 a-c$ has focused on using in vivo and physiochemical analysis to understand the proposed mechanisms of whey protein-derived mouthdrying alongside collecting sensory data. Key limitations are, however, associated with these methods: (1) researchers are only able to provide correlations between potential underpinning mechanisms and sensory data, and therefore, are unable to prove relationships; (2) a lack of research involving the human mouth, apart from the oral retention method developed by our research group $[89,134,136]$; (3) the ongoing challenge of quantifying mouthdrying using a 'physical measure' at the same time as scoring mouthdrying perception within products; (4) there is no defined mouthdrying threshold test to quantify individual sensitivity; (5) few studies have explored the role of individual differences on mouthdrying using consumers.Despite mouthdrying sensations being present in different whey protein-fortified food matrices, the majority of cited studies which have investigated mouthdrying in the solid food matrices have only used sensory methods (Table 3a-c) $[90,93,94]$. Therefore, less is known about potential mechanisms involved compared with a WPB. It is likely that within a dry low moisture system, such as a solid food, particles could aggregate or adhere to the oral cavity, causing friction [137] resulting in subsequent mouthdrying sensations. Furthermore, the strength of the interaction could be influenced by saliva, with adhesion, friction, surface tension and salivary viscosity being 
considered contributing factors [137]. In addition, a previous review of mucoadhesion in food systems suggested mucoadhesion strength could potentially be increased within a solid model from food product absorbing water from the oral cavity, promoting interactions, leading to swelling and spreading, as well as strengthened mucoadhesion [138]. Similarly, as alluded to by Celebioglu et al., hydrophobic and hydrophilic interactions [135] could also be relevant within a solid model, for example causing mouthdrying by causing poor dispersion between whey protein and saliva.

Table 2. Commonly proposed causes of whey protein beverage (WPB) derived mouthdrying adapted from Norton et al. [89] and associated limitations.

\begin{tabular}{|c|c|c|c|c|c|}
\hline Proposed Cause & WPB Model ${ }^{1}$ & & Description & & Limitations \\
\hline $\mathrm{pH}$ of WPB & $\begin{array}{c}\text { WPC }[86,122], \text { WPI } \\
{[124,139], \text { WPI, } \beta-\mathrm{LG} \text { and LF }} \\
{[125,126]}\end{array}$ & o & $\begin{array}{l}\text { Low } \mathrm{pH} \text { can cause } \\
\text { precipitation of the protein }\end{array}$ & $\circ$ & $\begin{array}{l}\text { There is evidence of } \\
\text { mouthdrying from WPB at } \\
\text { both low and neutral pH }\end{array}$ \\
\hline $\begin{array}{l}\text { Saliva and protein } \\
\text { interactions }\end{array}$ & $\begin{array}{l}\beta \text {-LG [123], WPI }[124,127] \\
\text { WPI, } \beta \text {-LG and LF }[125,126]\end{array}$ & $\circ$ & $\begin{array}{l}\text { Perception of mouthdrying } \\
\text { has links to saliva and } \\
\text { protein interactions }\end{array}$ & $\circ$ & $\begin{array}{l}\text { Studies have used in vivo } \\
\text { analysis mixing human or } \\
\text { artificial saliva with whey } \\
\text { proteins, but this requires } \\
\text { sensory analysis to correlate } \\
\text { instrumental data with } \\
\text { mouthdrying }\end{array}$ \\
\hline $\begin{array}{l}\text { Reduced lubrication } \\
\text { from saliva }\end{array}$ & $\beta$-LG [128] & $\circ$ & $\begin{array}{l}\text { Increased friction within the } \\
\text { oral cavity from reduced } \\
\text { lubrication }\end{array}$ & $\circ$ & $\begin{array}{l}\text { Using instrumental analysis } \\
\text { (such as tribology) to } \\
\text { predict in-mouth } \\
\text { experiences, but this } \\
\text { requires sensory analysis to } \\
\text { correlate instrumental data } \\
\text { with mouthdrying }\end{array}$ \\
\hline $\begin{array}{l}\text { Adhesion and } \\
\text { binding properties }\end{array}$ & $\begin{array}{l}\text { WPC }[89,134], \beta-L G \text { and LF } \\
{[140], \text { WPI }[130], \beta-L G[131]}\end{array}$ & $\circ$ & $\begin{array}{l}\text { Whey proteins binding to } \\
\text { oral epithelial cells, proteins } \\
\text { remaining on surfaces, } \\
\text { mucoadhesive properties, } \\
\text { increased oral retention and } \\
\text { whey protein adhering to } \\
\text { the oral cavity }\end{array}$ & $\circ$ & $\begin{array}{l}\text { In vivo, animal models, } \\
\text { small subject size, without a } \\
\text { non-protein source control, } \\
\text { but this requires sensory } \\
\text { analysis to correlate } \\
\text { instrumental data with } \\
\text { mouthdrying }\end{array}$ \\
\hline Heating time & WPC [86], RW [133] & $\circ$ & $\begin{array}{l}\text { Mouthdrying is considered } \\
\text { to increase with product } \\
\text { heating time, potentially } \\
\text { due to protein denaturation }\end{array}$ & $\circ$ & $\begin{array}{l}\text { Mouthdrying is present in } \\
\text { samples without heat } \\
\text { treatment, albeit at lower } \\
\text { levels, so this cannot be the } \\
\text { sole cause }\end{array}$ \\
\hline
\end{tabular}

${ }^{1}$ Whey protein beverage (WPB) model: whey protein concentration (WPC), whey protein isolate (WPI), $\beta$-lactoglobulin ( $\beta$-LG), lactoferrin (LF) and rennet whey (RW). 
Table 3. (a) Sensory methods commonly used to investigate whey protein-derived mouthdrying. (b) Physiochemical analysis commonly used to investigate whey protein-derived mouthdrying. (c) In vivo analysis commonly used to investigate whey protein-derived mouthdrying.

(a) Sensory methods commonly used to investigate whey protein-derived mouthdrying.

\begin{tabular}{|c|c|c|c|c|c|}
\hline Method & Food Matrix & & Description & & Limitations \\
\hline \multicolumn{6}{|c|}{ Sensory methods using trained panel or consumers. Key limitation: unable to explain the cause of mouthdrying } \\
\hline $\begin{array}{l}\text { Descriptive analysis } \\
\text { using a trained } \\
\text { sensory panel }^{1,2}\end{array}$ & $\begin{array}{c}\text { Cakes and biscuits [90], } \\
\text { WPB } \\
{[83,86,91,92,123-} \\
126,140-142], \text { rye bread } \\
\text { and cream cheese [94] }\end{array}$ & ○ & $\begin{array}{l}\text { Provides an objective sensory } \\
\text { measure of mouthdrying }\end{array}$ & ○ & $\begin{array}{l}\text { Studies have used different } \\
\text { methods (such as Spectrum }^{\mathrm{TM}} \\
\text { and QDA } \\
\text { numbers of attributes ( } 2 \text { to } 36) \\
\text { and there are potential issues } \\
\text { with providing a standard } \\
\text { mouthdrying reference to } \\
\text { ensure consistency across } \\
\text { studies }\end{array}$ \\
\hline $\begin{array}{l}\text { Threshold using a } \\
\text { trained sensory } \\
\text { panel }{ }^{1}\end{array}$ & WPB $[123,139,140]$ & ○ & $\begin{array}{l}\text { Evaluates mouthdrying } \\
\text { intensity strength compared } \\
\text { with protein concentration }\end{array}$ & ○ & $\begin{array}{l}\text { Studies have rated } \\
\text { mouthdrying intensity using } \\
\text { different methods (for example: } \\
0-5 \text { and } 0-7 \text { scales, Spectrum }{ }^{\mathrm{TM}} \\
\text { and scalar scoring), different } \\
\text { types of whey protein } \\
\text { beverages and studies have } \\
\text { used varying number of } \\
\text { panelists (7-12 panelists) }\end{array}$ \\
\hline $\begin{array}{l}\text { Sequential profiling } \\
\text { and time intensity } \\
\text { methods using } \\
\text { trained sensory } \\
\text { panels }{ }^{1}\end{array}$ & WPB [86,122-124] & ० & $\begin{array}{l}\text { Sequential profiling measures } \\
\text { changes in sensory attributes } \\
\text { with repeated consumption and } \\
\text { time intensity provides data on } \\
\text { time, duration and intensity of } \\
\text { mouthdrying }\end{array}$ & ○ & $\begin{array}{l}\text { Typically, sequential profiling } \\
\text { methods have not solely } \\
\text { focused on mouthdrying and } \\
\text { there are also potential issues } \\
\text { with providing a standard } \\
\text { mouthdrying reference to } \\
\text { ensure consistency across } \\
\text { studies }\end{array}$ \\
\hline $\begin{array}{l}\text { Sensory methods } \\
\text { using consumers } 1,2\end{array}$ & $\begin{array}{l}\text { WPB [ } 83,89,91,92,143], \\
\text { cakes and biscuits [90], } \\
\text { muffins [93], rye bread } \\
\text { and cream cheese [94] }\end{array}$ & ○ & $\begin{array}{l}\text { Provides feedback on products } \\
\text { using the target consumer } \\
\text { population. Common methods } \\
\text { to evaluate mouthdrying } \\
\text { include focus group sessions, } \\
\text { 9-point hedonic liking, } \\
\text { Just-About-Right (JAR), } \\
\text { generalised linear magnitude } \\
\text { scale (gLMS), visual analogue } \\
\text { scale (VAS) and two-alternative } \\
\text { forced choice test (2-AFC). }\end{array}$ & $\circ$ & $\begin{array}{l}\text { Limited studies have tested } \\
\text { mouthdrying using consumers } \\
\text { and there are potential issues } \\
\text { with test sensitivity of methods } \\
\text { used. Carter et al. noted } \\
\text { consumers are untrained and } \\
\text { potentially less able to quantify } \\
\text { mouthdrying objectively [46]. }\end{array}$ \\
\hline
\end{tabular}

\footnotetext{
${ }^{1}$ Refers to studies using a whey protein liquid model (whey protein beverage: WPB); ${ }^{2}$ refers to studies using a whey protein solid model.
} 
Table 3. Cont.

(b) Physiochemical analysis commonly used to investigate whey protein-derived mouthdrying.

\begin{tabular}{|c|c|c|c|c|c|}
\hline Method & WPB Model & & Description & & Limitations \\
\hline \multicolumn{6}{|c|}{ Physiochemical analysis. Key limitation: requires sensory data to provide correlations } \\
\hline Taste sensor ${ }^{1 *}$ & WPI, PWP, aPWP [139] & $\circ$ & $\begin{array}{l}\text { Measures the change in } \\
\text { membrane potential as a } \\
\text { result of adsorption }\end{array}$ & ० & $\begin{array}{l}\text { Analysis has been carried out in } \\
\text { low pH WPBs; therefore, this } \\
\text { method may not be suitable for } \\
\text { neutral pH WPBs }\end{array}$ \\
\hline Turbidity ${ }^{1 * \#}$ & $\begin{array}{l}\beta \text {-LG [123], WPI [124], } \\
\beta-L G \text { and LF 126] }\end{array}$ & o & $\begin{array}{l}\text { Measures aggregation of } \\
\text { protein and saliva }\end{array}$ & ० & $\begin{array}{l}\text { Saliva has been mixed artificially } \\
\text { with whey protein and this may } \\
\text { differ to saliva samples collected } \\
\text { post beverage consumption } \\
\text { Saliva samples in the referenced } \\
\text { studies were only collected from } \\
2-5 \text { volunteers; however, saliva is } \\
\text { considered to vary between } \\
\text { individuals } \\
\text { Turbidity in isolation is unlikely to } \\
\text { explain the cause of mouthdrying }\end{array}$ \\
\hline $\begin{array}{l}\text { Electrophoresis } \\
\text { analysis } 1 * \#\end{array}$ & $\beta-L G$ and LF $[125,126]$ & $\circ$ & $\begin{array}{l}\text { Determines protein } \\
\text { composition using } \\
\text { SDS-PAGE (sodium dodecyl } \\
\text { sulfate polyacrylamide gel } \\
\text { electrophoresis) }\end{array}$ & ० & $\begin{array}{l}\text { As for turbidity: saliva has been } \\
\text { mixed artificially with whey } \\
\text { protein; saliva samples only } \\
\text { collected from } 2-5 \text { volunteers }\end{array}$ \\
\hline $\begin{array}{l}\text { Dynamic Light } \\
\text { Scattering }{ }^{1 * \#}\end{array}$ & $\begin{array}{c}\text { WPC [86], } \beta-L G \text { and LF } \\
{[126]}\end{array}$ & ० & $\begin{array}{l}\text { Measures the size and } \\
\text { distribution of protein } \\
\text { and/or with saliva }\end{array}$ & $\circ$ & $\begin{array}{l}\text { As for turbidity: saliva has been } \\
\text { mixed artificially with whey protein } \\
\text { Particle size in WPB increases with } \\
\text { heating time, however, } \\
\text { mouthdrying is also present in } \\
\text { unheated WPBs. Therefore, particle } \\
\text { size in isolation is unlikely to } \\
\text { explain the cause of mouthdrying }\end{array}$ \\
\hline Zeta potential ${ }^{1 * \#}$ & $\begin{array}{c}\text { WPC [86], } \beta-\mathrm{LG} \text { and LF } \\
{[126,140]}\end{array}$ & o & $\begin{array}{l}\text { Measures electrostatic } \\
\text { interactions of protein, with } \\
\text { or without saliva }\end{array}$ & ० & $\begin{array}{l}\text { Bull et al. identified within a } \\
\text { neutral pH that WPBs (samples } \\
\text { varying in levels of heat treatment) } \\
\text { had similar zeta potential scores, } \\
\text { therefore proposed mouthdrying in } \\
\text { this study was not related to } \\
\text { electrostatic interactions and } \\
\text { proposed other mechanisms could } \\
\text { be involved. However, saliva was } \\
\text { not collected in this study [86]. }\end{array}$ \\
\hline $\begin{array}{l}\text { Portable infrared } \\
\text { spectrometer }^{1 *}\end{array}$ & WPI, WPC, WPH [141] & o & $\begin{array}{l}\text { Predicts mouthdrying in } \\
\text { low pH WPB }\end{array}$ & o & $\begin{array}{l}\text { This method was only tested in low } \\
\text { pH WPBs; therefore, this method } \\
\text { may not relate to mouthdrying } \\
\text { from neutral pH WPBs }\end{array}$ \\
\hline Tribology $1 *$ & $\beta-L G[128]$ & ० & $\begin{array}{l}\text { Measures friction and } \\
\text { lubrication }\end{array}$ & $\circ$ & $\begin{array}{l}\text { In some conditions (i.e. increasing } \\
\text { protein concentration from } 0.5 \text { to } \\
4 \% \text { ) sensory results were unable to } \\
\text { correlate with tribology data }\end{array}$ \\
\hline
\end{tabular}

\footnotetext{
${ }^{1}$ Refers to studies using a whey protein beverage (WPB) model (whey protein isolate (WPI), process whey protein (PWP), acidic process whey protein (aPWP), whey protein concentration (WPC), whey protein hydrolysate (WPH), $\beta$-lactoglobulin ( $\beta$-LG) and lactoferrin (LF); ${ }^{2}$ refers to studies using a whey protein solid model; *denotes studies using a low pH WPB model; \# denotes studies using a neutral $\mathrm{pH}$ WPB model.
} 
Table 3. Cont.

(c) In vivo analysis commonly used to investigate whey protein-derived mouthdrying.

\begin{tabular}{|c|c|c|c|c|c|}
\hline \multirow[t]{2}{*}{ Method } & WPB Model & \multicolumn{2}{|r|}{ Description } & \multicolumn{2}{|r|}{ Limitations } \\
\hline & \multicolumn{5}{|c|}{ In vivo analysis. Key limitation: requires sensory data to provide correlations } \\
\hline Saliva flow ${ }^{1 *}$ & $\beta$-LG [123] & ○ & $\begin{array}{l}\text { Evaluates saliva flow } \\
\text { following different } \\
\text { stimulants and relating this } \\
\text { to whey protein-derived } \\
\text { mouthdrying }\end{array}$ & $\circ$ & $\begin{array}{l}\text { Studies have been limited by the } \\
\text { number of saliva samples which } \\
\text { can be collected within one session } \\
\text { and this referenced study was } \\
\text { limited by a relatively small sample } \\
\text { size ( } 10 \text { volunteers) with a gender } \\
\text { imbalance ( } 2 \text { males and } 8 \text { females) }\end{array}$ \\
\hline Animal models ${ }^{1} \#$ & $\beta$-LG [131] & ○ & $\begin{array}{l}\text { Measures the adhesion of } \\
\text { proteins to porcine oral } \\
\text { mucosa tissue }\end{array}$ & o & $\begin{array}{l}\text { Methods need to be adapted to } \\
\text { enable human investigation }\end{array}$ \\
\hline Oral retention ${ }^{1} \#$ & WPC $[89,134]$ & ○ & $\begin{array}{l}\text { Measures the protein } \\
\text { remaining in saliva samples } \\
\text { post beverage consumption }\end{array}$ & ○ & $\begin{array}{l}\text { Previous limitations were small } \\
\text { subject size and no non-protein } \\
\text { control; more recent limitations } \\
\text { include the link between } \\
\text { mucoadhesion and mouthdrying } \\
\text { within the same method have not } \\
\text { been investigated }\end{array}$ \\
\hline $\begin{array}{l}\text { Dynamic in vivo } \\
\text { models }\end{array}$ & WPI [127] & ○ & $\begin{array}{l}\text { Aims to replicate in-mouth } \\
\text { beverage consumption by } \\
\text { measuring whey protein } \\
\text { and saliva interactions }\end{array}$ & $\circ$ & $\begin{array}{l}\text { Models were estimated based on } \\
\text { limited data from the literature, } \\
\text { therefore may not fully reflect } \\
\text { individual variability }\end{array}$ \\
\hline
\end{tabular}

\footnotetext{
${ }^{1}$ Refers to studies using a whey protein beverage (WPB) model (whey protein concentration (WPC), whey protein isolate (WPI), $\beta$-lactoglobulin $(\beta-\mathrm{LG}){ }^{2}$ refers to studies using a whey protein solid model; ${ }^{*}$ denotes studies using a low $\mathrm{pH}$ WPB model; \# denotes studies using a neutral pH WPB model.
}

Strategies to reduce mouthdrying have been previously investigated with limited success. For example, Withers et al. tested different mouthdrying mitigation strategies using a sensory trained panel by adding sucrose ( $3 \% \mathrm{wt} / \mathrm{wt})$, modulating viscosity by adding a starch thickener $(1.8 \% \mathrm{wt} / \mathrm{wt})$ and increasing fat levels by using both sunflower oil and milk fat $(2 \% \mathrm{wt} / \mathrm{wt})$, and concluded that all these strategies had minimal effect on mouthdrying in dairy beverages at the tested levels [122]. This highlights the challenges associated with suppressing mouthdrying and a need to understand better the potential mechanism involved in mouthdrying to enable improved mitigation strategies to be developed [122].

In summary, addressing and understanding the proposed causes of mouthdrying is important to increase the enjoyment derived from products and subsequent compliance. Texture has a key role in food preferences and learning from astringency related oral drying can provide useful insights into whey protein-derived mouthdrying.

\subsection{Mucoadhesion and Mouthfeel Perception}

There is a growing interest in the mucoadhesion phenomenon and its associated prolonged 'oral exposure', which may influence sensory perception [138]. Our research group has proposed mucoadhesion to be the probable cause of whey protein-derived mouthdrying particularly in beverages at near-neutral $\mathrm{pH}$. A proposed WPB mucoadhesion mechanism is outlined in Figure 3.

Mucoadhesion is a concept that has been well utilised in drug delivery systems due to its ability to enhance retention at mucosal membranes [144-147] and has more recently been considered in a food context [138]. Mucoadhesion can be simply described as the adhesion of materials to mucosal membranes (moist surfaces lining the walls of different body cavies) [147]. Mucoadhesion can result from different physicochemical 
interactions, such as hydrogen bonding, hydrophobic interactions, electrostatic interactions, Van der Waals forces and disulphide bridges [144,148,149]. Mucoadhesion can be explained based on different theories, for example, wetting, mechanical, electronic, diffusion, dehydration and adsorption [147]. Two different stages have been cited in establishing mucoadhesion $[144,147]$. The first is a contact phase which can occur from the adhesion of a material (e.g., whey protein) to the mucosal membrane (oral mucosa), resulting in spreading and swelling) $[144,147]$. The second is a consolidation phase resulting from physicochemical interactions, which lead to stronger adhesion [144,147]. Mucoadhesion has often been measured using physical techniques (rheological, optical and spectroscopic) and in vivo methods (tensile, rotating disc, flow-through, tribology and oral retention) $[89,128,134,136,147]$.

Mucoadhesion is considered in the context of this review to be the binding or sticking of whey proteins to the oral cavity (cheeks, gums and tongue) [86]. In order to measure such adhesion to the oral cavity within humans, our research group developed an oral retention method $[134,136]$. This method enables researchers to measure the amount of protein retained in the mouth over time by measuring protein concentration in saliva samples [134]. However, the key limitation of this method has related to a very small subject sample size and the absence of a non-protein source control. More recently, Norton et al. validated the oral retention method by establishing that WPB consumption significantly increased protein content in saliva samples post beverage, compared with a non-protein control (whey permeate beverage) using a group of younger consumers [89]. Furthermore, factors such as saliva flow, composition and viscosity are considered to influence retention of samples [136]. Accordingly, it is proposed that a reduced saliva flow could lead to greater mucoadhesion as a result of increased tissue exposure, adhesion and interactions from proteins within the oral cavity [134]. Recent work by our research group highlighted that reduced salivary flow rate correlated with increased mucoadhesion; however, differences in saliva flow had no significant influence on mouthdrying perception [89]. Therefore, we conclude the need for further research in this area involving more sensitive salivary flow rate methods, as well as including the rating of mouthdrying perception within such methods (a key limitation as alluded to in Table $3 a-c$ ) to enable better correlations with mucoadhesion.

The extent of mucoadhesion within older adults is relatively unknown. However, it is proposed that mucoadhesion is likely to be strengthened within an ageing population as (a) sensitivity to mouthdrying can increase with age [143] and (b) salivary flow rates can decrease with age [101]. Recently, we investigated this phenomenon in 84 consumers (42 younger adults aged 18-30 years and 42 older adults aged 65 years or over) [89]. Older adults had significantly increased protein concentration in saliva samples post WPB consumption, regardless of the extent of whey protein heat treatment, compared with younger adults [89]. This suggests mucoadhesion increases with age and could result in a prolonged drying sensation; however, this latter point needs further proof. Understanding the potential mechanisms involved in whey protein-derived mouthdrying will be key to ensure products are optimised so as to ensure the benefits associated with consumption of whey protein-fortified products are achieved by older adults.

In summary, mucoadhesion is a relatively new area within mouthfeel perception and early indications suggest mucoadhesion has a role as a potential cause of mouthdrying. However, this is yet to be proven, and therefore, future work should address this phenomenon, as well as identifying whether mucoadhesion is present in different food models and considering the role that individual differences may have on mucoadhesion. 


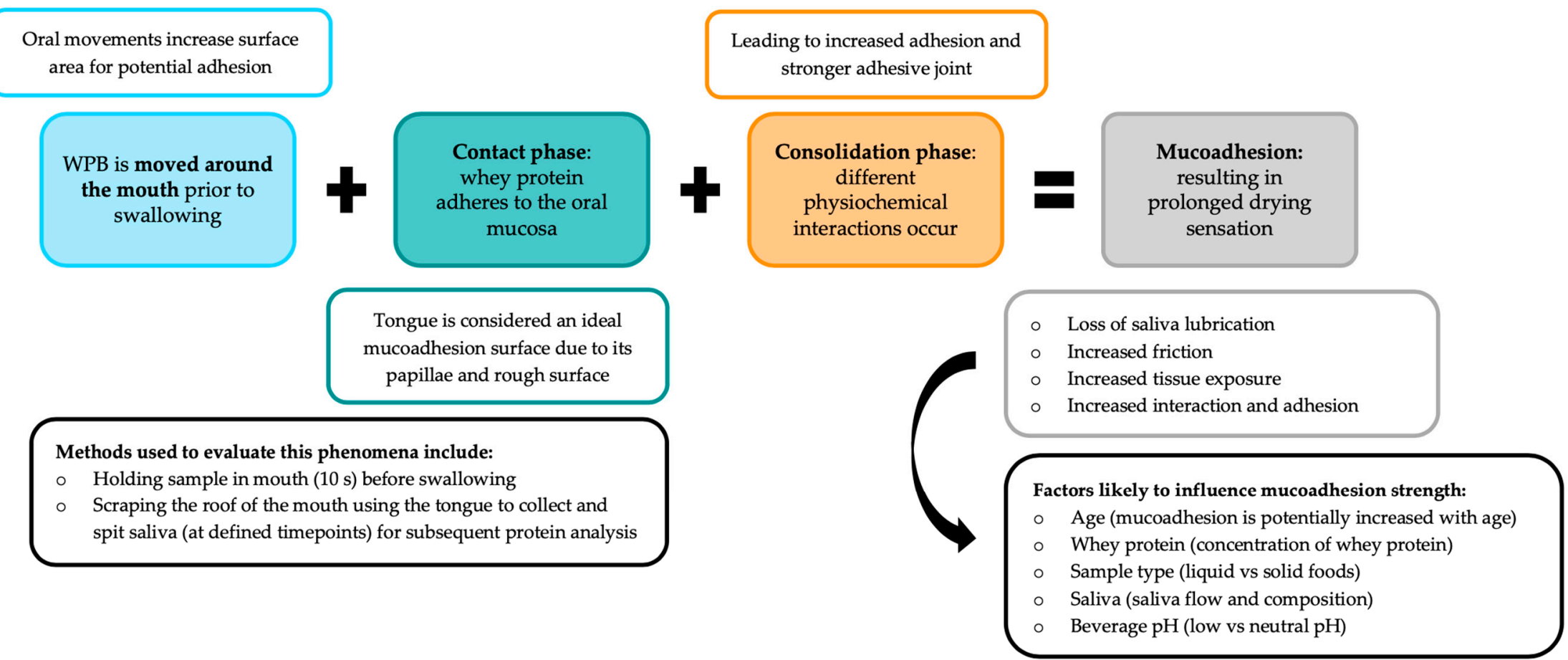

Figure 3. Proposed mucoadhesion mechanism of neutral pH whey protein beverages (WPB) $[89,128,134,136,138,144,147]$. 


\section{Age and Individual Differences Likely to Influence Mouthfeel Perception}

Sensory perception is considered to alter with age. The most obvious age-associated changes relate to vision and hearing, although touch and pain thresholds also increase with age $[150,151]$. It is well documented that taste impairments and loss of smell are commonly associated with ageing. For example, older adults have increased taste detection thresholds across all taste modalities and accordingly perceived taste perception declines with age [152]. Olfactory function also reduces with age and the combination of taste and olfactory decline can result in older adults often perceiving foods to lack flavour [25,152-154] (ageing and taste has been reviewed previously see Methven et al. [152]). Age has been shown to have varying effects on texture and mouthfeel perception. For example, studies have shown that older adults perceived soups as less creamy, sweet waffles as less fatty and elastic and dairy beverages as more mouthdrying compared with younger adults $[143,155,156]$. However, in other studies the effects of age have been less apparent, such as perceived thickness and mouthcoating of dairy beverages remaining consistent between younger and older age groups [143]. Again, in a study comparing different nut types using temporal dominance of sensations, the overall progression of dominant attributes during chewing was consistent between age groups [157]. Older adults did however select hardness as a more dominant attribute compared with younger adults [157]. This suggests some aspects of texture perception are potentially preserved with age, however, this could be attribute and product dependent. Accordingly, these changes can influence food choice, potentially making food less interesting and enjoyable, and therefore may increase the risk of poor nutritional status. Currently, less is known about how mouthfeel perception changes with age. Moreover, it has been suggested by previous authors that a greater emphasis could be placed on mouthfeel sensations to compensate for taste and smell loss in older adults [158].

\subsection{Whey Protein-Derived Mouthdrying and Changes in Perception with Age}

Surprisingly, despite multiple high protein products being available on the market and whey protein-fortified products being commonly used to improve nutritional status, these products are typically not designed with, or for, older adults. Withers et al. suggested some aspects of texture perception are influenced by age, as older adults reported greater sensitivity to mouthdrying compared with younger adults following consumption of dairy beverages [143]. This study investigated mouthdrying by comparing a heated rennet whey sample with a skimmed milk sample using a paired comparison test [143]. Only the older adults were able to distinguish the rennet sample as more mouthdrying [143]; rennet whey was proven previously to be a source of mouthdrying [133]. However, two more recent studies by our research group $[89,90]$ have been unable to demonstrate an overall effect of age on mouthdrying in different whey protein food models using a gLMS (generalised linear magnitude scale) and VAS (visual analogue scale) $[89,90]$. They concluded that within a liquid model using WPBs, the potential cause of the minimal effect between age groups related to the lack of sensitivity of the gLMS compared with a paired comparison test [89]. Whereas, in the solid model, which used two different methods (a single point in time and a full portion size at home), the older adults were able to perceive the protein cakes and biscuits as more mouthdrying compared with the control versions [90]. This supported Withers et al. findings [143] but did not reach overall significance and highlighted the challenges with measuring mouthdrying within an older population and ensuring a suitable test is selected to measure such mouthdrying.

Sensory testing needs to replicate normal eating behaviour and measure changes in consumption over repeated consumption, rather than just a single sip or bite. This is especially relevant to products such as ONS, which are associated with changes in liking and mouthfeel with multiple sips $[85,87,88]$. This demonstrates the challenges within older adults of balancing the appropriate volume to replicate normal consumption versus sample fatigue from too many samples [38] (for a review of sensory and consumer methodology in older adults, see Methven et al. [38]). Moreover, to measure effectively changes in the 
perception of mouthdrying with age, it is important to ensure the methods to be used are suitable for a broad range of older adults within a test group, so as to secure useful and meaningful results.

\subsection{Individual Differences That Could Influence Perception of Whey Protein-Fortified Products}

Individuals are defined by differences that distinguish them from others and such differences can influence sensory perception. For example, consumers typically differ in physiology (such as age, biological sex, health status and associated medications, appetite, dental status, saliva flow, muscle strength, sensory acuity-including differences in taste, olfaction and oral tactile sensitivity), social factors (such as cultural and demographic groups) and preferences (such as food preferences, mouth behaviour and food neophobia) [159-166]. When designing products for older adults, individual differences are likely to influence perception. Accordingly, these differences will be explored in the following sections with a specific focus on their relevance for older adults. Table 4 highlights that individual differences, such as age, oral health, saliva and food oral processing are considered to have a role within sensory perception. However, currently the extent of the effect of such individual differences on the perception of whey protein-derived mouthdrying is relatively uncertain. 


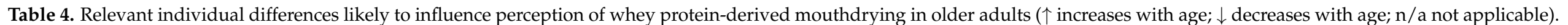

\begin{tabular}{|c|c|c|c|c|c|c|c|}
\hline Category & Factors & Effect of Age & & Effect on Mouthdrying & Food Matrix & & Methodology Limitations \\
\hline \multirow[t]{5}{*}{ Physiology } & $\operatorname{Age}^{1 *}$ & $\mathrm{n} / \mathrm{a}$ & $\circ$ & $\begin{array}{l}\text { Whey protein fortified products cause mouthdrying which } \\
\text { may be influenced by age }\end{array}$ & $\begin{array}{l}\text { WPB [89,143], cakes and } \\
\text { biscuits [90] }\end{array}$ & $\circ$ & $\begin{array}{l}\text { Inconsistent results between } \\
\text { studies could result from } \\
\text { differences in test sensitivity used } \\
\text { (for example, paired comparison } \\
\text { test vs generalised labelled } \\
\text { magnitude scale) }\end{array}$ \\
\hline & Appetite ${ }^{1,2 * \#+}$ & $\downarrow$ & $\circ$ & $\begin{array}{l}\text { ONS and whey protein-fortified products can increase } \\
\text { perceived thirst, reduce hunger and prospective } \\
\text { consumption }\end{array}$ & Cupcakes [90], ONS $[87,88]$ & $\circ$ & $\begin{array}{l}\text { Self-report using visual analogue } \\
\text { scale. Appetite was not measured } \\
\text { at subsequent meals }\end{array}$ \\
\hline & Dental status ${ }^{1,2 *} \dagger$ & $\downarrow$ & $\circ$ & $\begin{array}{l}\text { Poor dental status could make consumption of solid foods } \\
\text { more difficult and therefore negatively impact product } \\
\text { liking }\end{array}$ & $\begin{array}{l}\text { Cakes and biscuits [90], meat } \\
\text { and cereal [28] }\end{array}$ & $\circ$ & $\begin{array}{l}\text { Self-report questionnaire or limited } \\
\text { oral parameters measured }\end{array}$ \\
\hline & Saliva flow ${ }^{1,2 * \#}$ & $\downarrow$ & $\circ$ & $\begin{array}{l}\text { Saliva flow can decrease with age, however whether this } \\
\text { influences subsequent perception is relatively unclear }\end{array}$ & $\begin{array}{c}\text { WPB [89,123], cakes and } \\
\text { biscuits [90], meat and cereal } \\
\text { [28] }\end{array}$ & $\circ$ & $\begin{array}{l}\text { Volunteers may have been too } \\
\text { healthy to demonstrate an effect of } \\
\text { saliva flow }\end{array}$ \\
\hline & $\begin{array}{l}\text { Detection thresholds to } \\
\text { sensory stimuli }{ }^{1} \#\end{array}$ & $\uparrow$ & $\circ$ & $\begin{array}{l}\text { Detection thresholds for many stimuli (such as tastants } \\
\text { and volatile compounds) increase with age and perception } \\
\text { increases (at different rates depending on the stimuli) with } \\
\text { stimuli intensity. Studies to date suggest that perceived } \\
\text { mouthdrying initially increases with protein concentration } \\
\text { until a plateau is reached. }\end{array}$ & WPB $[83,123,139,140]$ & $\circ$ & $\begin{array}{l}\text { No defined mouthdrying threshold } \\
\text { method has been developed }\end{array}$ \\
\hline Social & Culture $^{2 *}$ & $\mathrm{n} / \mathrm{a}$ & $\circ$ & $\begin{array}{l}\text { Cultural groups have different food oral processing } \\
\text { behaviour and this could influence food choice and } \\
\text { mouthfeel perception }\end{array}$ & $\begin{array}{c}18 \text { different food products } \\
\text { varying in physical properties } \\
\text { [162] carrot, cheese and } \\
\text { sausage [163] }\end{array}$ & $\circ$ & $\begin{array}{l}\text { Only limited populations have } \\
\text { been studied (for example Dutch } \\
\text { nationality and Caucasian ethnicity } \\
\text { compared with Chinese nationality } \\
\text { and Asian ethnicity) }\end{array}$ \\
\hline \multirow[t]{2}{*}{ Preferences } & $\begin{array}{l}\text { Food preference and } \\
\text { neophobia }{ }^{2} \ddagger\end{array}$ & No set direction & $\circ$ & $\begin{array}{l}\text { Food preferences and neophobia could influence } \\
\text { compliance with ONS and whey protein-fortified products }\end{array}$ & $\mathrm{n} / \mathrm{a}[161,164]$ & $\circ$ & Self-report questionnaire \\
\hline & Mouth behaviour ${ }^{1 *}$ & Not known & $\circ$ & $\begin{array}{l}\text { Mouth behaviour could influence texture perception of } \\
\text { whey protein-fortified products and may alter with age }\end{array}$ & Cakes and biscuits [90] & $\circ$ & Self-report questionnaire \\
\hline
\end{tabular}

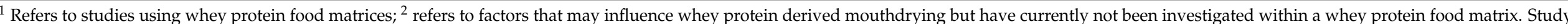

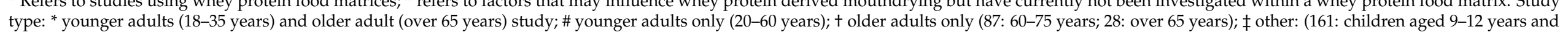
parents; $164:$ n/a review paper). All volunteers considered healthy unless otherwise stated. 


\subsection{Food Oral Processing and Mouthfeel Perception}

The oral cavity consists primarily of lips, gums, cheeks, hard and soft palates, teeth, tongue, salivary glands, orofacial muscles and mucous membranes [150,167]. The oral mucosa (three types within the oral cavity, namely lining, masticatory and specialised mucosa) is a moist soft tissue membrane lining the oral cavity providing key functions such as protection, lubrication and moistening $[150,168]$. Oral receptors respond to food digestion and processing, thereby leading to taste, odour, irritation and texture perceptions [160]. The mouth is considered a sensitive organ and receptors such as mechanoreceptors (touch and proprioception), which respond to tactile stimuli, are considered the most relevant for texture perception [160]. Although there is no specific texture receptor, texture is considered to be perceived by the tongue, palate and other soft tissues within the mouth [160]. For further details on oral cavity anatomy and physiology and relevant oral receptors within a food context, see references [150,160,168-170].

Individuals differ in their masticatory function, bite force, swallowing threshold, saliva volume and composition, oral receptors and sensitivity [159]. Therefore, it is combination of differences in food structure and individual oral physiology that cause variation in food oral processing and subsequently in sensory perception [170]. Differences in food oral processing influence perception not only of texture and mouthfeel, but also flavour, thereby affecting food choice and acceptability $[170,171]$. Mouth behaviour can be described as the way an individual manipulates food in their mouth and is considered to influence food choice, texture preference and satisfaction $[165,166]$. There are four major mouth behaviour groups: crunchers (individuals that like foods that break on biting) and chewers (those that prefer to chew foods), being considered the more predominant groups compared with suckers (those that prefer harder foods which can be sucked on) and smooshers (likers of soft foods and less mouth activity) $[165,166]$. Mouth behaviour (as outlined in Table 4) can also have implications for older adults. For example, a decline in dental status can influence food choice, resulting in a preference for softer foods rather than hard crunchy foods $[165,166]$.

Food lubrication within the mouth is considered to be influenced by size and concentration of oil droplets, viscosity of saliva, protein content of saliva and properties of the particles (size, shape and hardness) within the oral fluid and surface properties of the oral mucosa and teeth [172]. The role of oral lubrication in food intake is also a consideration; therefore, manipulating oral lubrication could be particularly relevant within older adults who are at increased risk of malnutrition and their saliva flow often being reduced [173].

Understanding changes in food oral processing with age is key to improving food intake, particularly in an older adult population. For example, older adults are considered to consume foods more slowly, have increased chewing duration and reduced tongue strength compared with younger adults $[162,174,175]$. Teeth loss is also associated with ageing, data from the 'Adult Dental Health Survey 2009-England' demonstrated edentate increasing with age from $1 \%$ at $45-54$ years, $5 \%$ at $55-64$ years, $15 \%$ at $65-74$ years, $29 \%$ at $75-84$ years and $45 \%$ at 85 years and over [176]. Teeth loss is also associated with reduced masticatory abilities [177], and Steele et al. noted from a study involving 1211 adults aged 60 years or over that having 21 or more natural teeth resulted in less eating problems [178]. Mastication behaviour can influence mouth behaviour preferences, texture perception of foods and food choice and intake, thereby impacting an individual's nutritional status $[179,180]$. For example, lower mucosal moisture has been associated with reduced and poor chewing capacity in older adults [181].

In summary, food oral processing is considered to play an important role in determining food choice and acceptance, with age-related changes likely to impact this further. Changes in food oral processing are likely to impact perception and acceptance of proteinfortified foods. Overall, an understanding of the differences between age groups and their sensory sensitivity will assist in the provision of more suitable food products to match the needs of older adults. 


\subsection{Differences in Saliva Flow with Age and Their Potential Effect on Mouthfeel Perception}

Saliva is a viscoelastic solution, consisting of approximately $99.5 \%$ water, with the remainder $(\sim 0.5 \%)$ being proteins, enzymes, electrolytes and nitrogenous products [150,182-184]. Saliva performs a key role in the maintenance of oral health, as well as enabling taste, providing a buffer capacity and mineralisation, aiding digestion and preventing tooth decay, as well as being a lubricant and having antimicrobial functions [182-184].

Saliva-related diseases can negatively impact oral health, quality of life, dietary habits and nutritional status [185]. For example, xerostomia (dry mouth) is a syndrome involving an absence of saliva and results in eating difficulties, tooth decay and oral candida infection and its prevalence is considered to increase with age [186]. Hyposalivation (reduced saliva flow) is typically cited as $<0.1$ and $0.5 \mathrm{~mL} / \mathrm{min}$ for unstimulated saliva and stimulated saliva flow, respectively $[185,187,188]$. It correlates with adverse health outcomes, as well as reduced taste perception, chewing and swallowing difficulties $[185,187,188]$. Common causes of hyposalivation include medication, dehydration and disease [185]. Prevalence of dry mouth within an older population is considered between $12-39 \%$ and increases with age [102].

There is evidence of age-related changes in saliva. For example, a review by $\mathrm{Xu}$ et al. highlighted salivary changes with age, supporting reduced saliva flow, changes in calcium and mucin content and increased ionic concentration influencing the quantity and quality of saliva [189]. A meta-analysis involving 47 studies concluded significantly reduced salivary flow rates in older adults, and this reduction was not considered to be related to use of medication [190]. Vandenberghe-Descamps et al. demonstrated that healthy older adults had $38.5 \%$ and $38 \%$ lower resting and stimulated salivary flows respectively when compared with younger adults and the results were independent of medication and dental status [101]. The acinar cells are considered to degenerate with age and can influence salivary flow rates [191]. Affoo et al. indicated a gland specific reduction in salivary flow rates in older adults and highlighted that the parotid gland and the minor glands are potentially less influenced by age [190]. An overview of saliva flow contributions from salivary glands [191] is outlined in Figure 4. The submandibular gland, which contributes $60 \%$ of unstimulated saliva production, has an increased sensitivity to metabolic and physiological changes, which is a proposed cause of greater changes seen in unstimulated saliva flow with age compared with stimulated saliva [191]. Accordingly, a reduced saliva flow is considered an issue and is commonly associated with decreased lubrication, protection, oral clearance, mucosal surfaces hydration and coating abilities within the oral cavity [192-195]. It is, therefore, likely to contribute to changes in food habits, further negatively impact nutritional status and alter sensory perception (Table 5). However, as stimulated saliva flow is potentially less influenced by age [190], this may minimise changes from saliva flow in response to food consumption and subsequent sensory perception. 


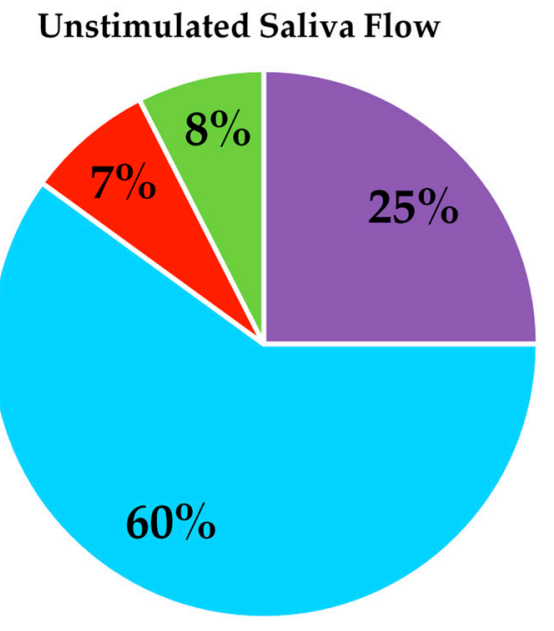

$\begin{array}{ll}\text { - Parotid Gland } & \text { "Submandibular Gland } \\ \text { - Sublingual Gland } & \text { = Minor Salivary Glands }\end{array}$
Stimulated Saliva Flow

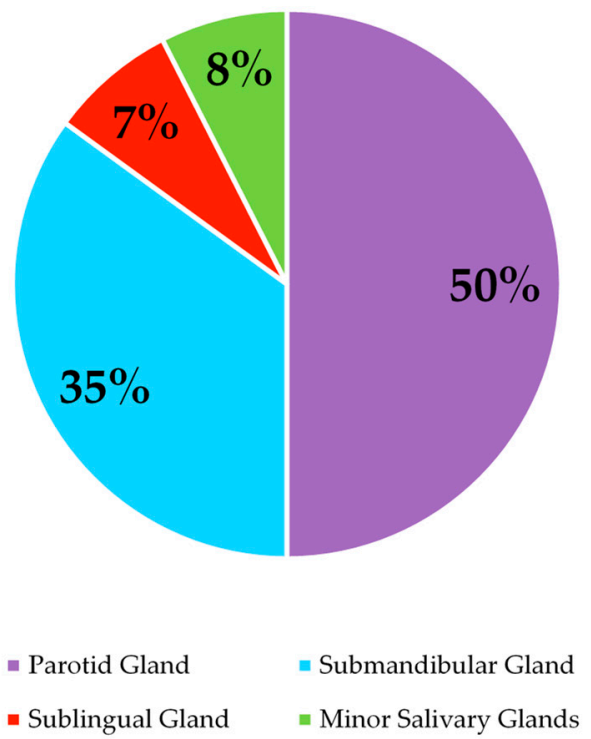

Figure 4. Saliva flow contribution from salivary glands [191].

Table 5. Summary of proposed food and saliva interactions and effect on sensory perception, as suggested by Mosca and Chen [196].

\begin{tabular}{|c|c|c|c|c|}
\hline Proposed Mechanism & & Description & & Sensory Perception \\
\hline $\begin{array}{l}\text { Surface coating and } \\
\text { wetting }\end{array}$ & $\circ$ & $\begin{array}{l}\text { This ensures lubrication, } \\
\text { food breakdown, bolus } \\
\text { formation and safe } \\
\text { swallowing }\end{array}$ & o & $\begin{array}{l}\text { Insufficient saliva can } \\
\text { result in drying } \\
\text { sensations }\end{array}$ \\
\hline Colloidal interactions & ० & $\begin{array}{l}\text { Colloidal food products } \\
\text { such as beverages and } \\
\text { emulsions can interact } \\
\text { with saliva causing } \\
\text { destabilisation }\end{array}$ & o & $\begin{array}{l}\text { Texture and mouthfeel } \\
\text { attributes }\end{array}$ \\
\hline Complexation & $\circ$ & $\begin{array}{l}\text { Reduction in saliva } \\
\text { lubrication and } \\
\text { increased friction }\end{array}$ & o & $\begin{array}{l}\text { Mouthdrying and } \\
\text { astringency sensations }\end{array}$ \\
\hline Enzymatic breakdown & ० & $\begin{array}{l}\text { Rheological properties } \\
\text { changes from amylase } \\
\text { activity and } \\
\text { macromolecules partial } \\
\text { hydrolysis }\end{array}$ & o & $\begin{array}{l}\text { Texture and flavour } \\
\text { perception }\end{array}$ \\
\hline Binding of aroma compounds & o & $\begin{array}{l}\text { Saliva dissolves tastants } \\
\text { and binds aroma }\end{array}$ & ० & Flavour perception \\
\hline
\end{tabular}

Food breakdown and perception of taste, flavour and texture of foods are all influenced by saliva, which affects the eating process and food intake [180,197]. Saliva provides a key role in our eating experience, with food oral processing and perception both being influenced by a number of food and saliva interactions as outlined in Table 5 [196]. Without saliva, food deformation, breakdown and destabilisation would be negatively influenced, 
along with food perception and swallowing [196]. In a food bolus, food particles are incorporated with saliva into something safe to swallow, and this process is in most cases considered automatic [198]. However, bolus formation and swallowing can provide additional risks in an older adult, thereby affecting an individual's food choice and intake [198]. Additionally, these processes are considered to be influenced by the surface coating of food particles, particle size distribution and saliva incorporation, with moisture content and type of food structure also influencing the volume of saliva required [196,198].

In terms of sensory perception, unstimulated saliva provides background taste, whilst stimulated saliva is part of the mechanical process during eating and can increase salivary flow rates by 5-50 times, with more than 50\% secreted from parotid glands [190,199]. As highlighted in Table 5, saliva is likely to contribute negatively to mouthfeel perception and could impact the perception of whey protein-derived mouthdrying. The spinnbarkeit test relates to the stringiness of saliva and its adhesion properties within the mouth; saliva provides lubrication and protection, both of which are considered important for sensory perception [200,201]. Altered or reduced viscoelasticity can impact mouthfeel perception, with viscoelasticity being noted to reduce with age [200,201]. Furthermore, it has been suggested that an altered aroma perception in older adults could be caused by reduced stimulated saliva flow [202]. There are challenges associated with understanding the role of saliva on subsequent perception, and these are partly due to methodology limitations (as highlighted in a recent review by Munoz-Gonzalez et al. [188]). Typically, studies have grouped volunteers into low or high saliva flow, often resulting in minimal effects on sensory perception $[28,89,90]$.

In summary, there is a clear need to understand how saliva can impact sensory perception and consumption of foods in older adults. The influence of saliva and agerelated changes in saliva on the sensory perception of foods, and specifically proteinfortified products, needs further investigation.

\section{Conclusions}

This review highlighted that individual differences (such as age, appetite, dental status, saliva flow, detection thresholds to sensory stimuli, cultural differences and preferences) could influence whey protein-derived mouthdrying, which in turn impacts the eating experience. Protein needs are considered to increase with age and protein consumption is associated with numerous benefits. More specifically, whey protein is commonly fortified into products due to its associated functional benefits. However, such products can elicit mouthdrying, which is considered to hinder consumption and acceptance. Therefore, improvements in such products are key to increasing liking and reducing wastage. Furthermore, mouthdrying is considered to increase with age, and despite previous investigations, the causes of whey protein-derived mouthdrying are currently not fully understood. Further research is needed to understand these, with mucoadhesion currently being a proposed, but as yet to be proven, cause. In addition, more research is needed into potential mitigation strategies (such as using fat, sucrose or adjusting viscosity) to modulate mouthdrying and their subsequent influence on consumer acceptance. Despite mouthdrying being present in both a liquid and solid food model, research has mainly focused on WPB mechanisms rather than solid model mechanisms; therefore, future research should look to address this gap within the literature. Individual differences, such as age, oral health, saliva and food oral processing, are considered to have a role within mouthfeel perception. However, currently, the effect of such individual differences on mouthdrying and mucoadhesion is relatively uncertain. If taking account of age and individual differences could lead to increased protein consumption by tailoring whey protein-fortified products to meet individual needs, then this could significantly improve nutritional status in older adults and help to reduce their susceptibility to malnutrition and sarcopenia. 
Author Contributions: Conceptualisation, V.N., L.M. and S.L.; writing—original draft preparation, V.N.; writing-review and editing, V.N., L.M. and S.L. All authors have read and agreed to the published version of the manuscript.

Funding: This research received no external funding.

Conflicts of Interest: The authors declare no conflict of interest.

\section{References}

1. United Nations. 2019. Available online: https://www.un.org/en/development/desa/population/publications/pdf/ageing/ WorldPopulationAgeing2019-Highlights.pdf (accessed on 18 November 2020).

2. Office for National Statistics. 2018. Available online: https://www.ons.gov.uk/peoplepopulationandcommunity/populationandmigration/ populationestimates/articles/overviewoftheukpopulation/november2018 (accessed on 2 January 2019).

3. World Health Organisation (WHO). 2015. Available online: https://www.who.int/ageing/events/world-report-2015-launch/ en/ (accessed on 4 January 2019).

4. World Health Organisation (WHO). Decade of Healthy Ageing 2020-2030. 2020. Available online: https://www.who.int/docs / default-source / decade-of-healthy-ageing / final-decade-proposal/decade-proposal-final-apr2020-en.pdf?sfvrsn=b4b75ebc_3 (accessed on 20 April 2020).

5. $\quad$ Pout, V. Older adults. In Manual of Dietetic Practice, 5th ed.; Gandy, J., Ed.; Wiley-Blackwell: Hoboken, NJ, USA, $2014 ;$ pp. 92-103.

6. Ahmed, T.; Haboubi, N. Assessment and management of nutrition in older people and its importance to health. Clin. Interv. Aging 2010, 5, 207-216.

7. Bauer, J.; Biolo, G.; Cederholm, T.; Cesari, M.; Cruz-Jentoft, A.J.; Morley, J.E.; Philips, S.; Sieber, C.; Stehle, P.; Teta, D.; et al. Evidence based recommendation for optimal dietary protein intake in older people: A position paper from the PROT-AGE study group. JAMA 2013, 14, 542-559. [CrossRef] [PubMed]

8. Deutz, N.E.P.; Bauer, J.M.; Barazzoni, R.; Biolo, G.; Boirie, Y.; Bosy-Westphal, A.; Cederholm, T.; Cruz-Jentoft, A. Protein intake and exercise for optimal muscle function with ageing: Recommendations from the ESPEN Expert Group. Clin. Nutr. 2014, 33, 929-936. [CrossRef]

9. Department of Health. 1992. Available online: https://assets.publishing.service.gov.uk/government/uploads/system/uploads/ attachment_data/file/743779/The_Nutrition_of_Elderly_People_1992_.pdf (accessed on 3 January 2019).

10. Dorrington, N.; Fallaize, R.; Hobbs, D.A.; Weech, M.; Lovegrove, J.A. A review of nutritional requirements of adults aged $\geq 65$ years in the UK. J. Nutr. 2020, 150, 2245-2256. [CrossRef] [PubMed]

11. Armarya, S.; Singh, K.; Sabharwal, M. Changes during ageing and their association with malnutrition. J. Clin. Gerontol. Geriatr. 2015, 6, 78-84. [CrossRef]

12. BDA. 2017. Available online: https://www.bda.uk.com/publications/professional/NutritionHydrationDigest.pdf (accessed on 10 January 2019).

13. BAPEN. 2018. Available online: https://www.bapen.org.uk/malnutrition-undernutrition/introduction-to-malnutrition?start=4 (accessed on 10 January 2019).

14. Hickson, M. Malnutrition and ageing. Postgrad. Med. J. 2006, 82, 2-8. [CrossRef]

15. Elia, M. Defining, recognizing and reporting malnutrition. Int. J. Low Extrem. Wonds 2017, 16, 230-237. [CrossRef] [PubMed]

16. Maleta, K. Undernutrition. Malawi. Med. J. 2006, 18, 189-205.

17. Leiji-Halfwerk, S.; Verwijs, M.H.; van Houdt, S.; Borkent, J.W.; Guaitoli, P.R.; Pelgrim, T.; Heymans, M.W.; Power, L.; Visser, M.; Corish, C.A.; et al. Prevalence of protein energy malnutrition risk in European older adults in community, residential and hospital settings, according to 22 malnutrition screening tools validated for use in adults $>65$ years. A systematic review and meta analysis. Maturitas 2019, 126, 80-89. [CrossRef]

18. Todorovic, V.; Russell, C.; Elia, M. The MUST Explanatory Booklet. 2003. Available online: https://www.bapen.org.uk/pdfs/ must/must_explan.pdf (accessed on 2 January 2019).

19. National Institute for Health and Care Excellence. 2017. Available online: https://www.nice.org.uk/guidance/cg32/chapter/1Guidance\#indications-for-nutrition-support-in-hospital-and-the-community (accessed on 8 January 2019).

20. Fielding, R.A.; Vellas, B.; Evans, W.J.; Bhasin, S.; Morley, J.E.; Newman, A.B.; Van Kan, G.A.; Andrieu, S.; Bauer, J.; Breuille, D.; et al. Sarcopenia: An undiagnosed condition in older adults. Current consensus definition: Prevalence, etiology and consequences. J. Am. Med. Dir. Assoc. 2011, 12, 249-256. [CrossRef]

21. von Haehling, S.; Morley, J.E.; Anker, S.D. An overview of sarcopenia: Facts and numbers on prevalence and clinical impact. J. Cachex. Sarcopenia Muscle 2010, 1, 129-133. [CrossRef]

22. Stevenson, E.; Brunstrom, J.; Johnstone, A.; Green, M.; Williams, L.; Corfe, B. Protein for Life Team. 2019. Available online: https://ktn-uk.co.uk/news/protein-for-life-a-framework-for-action (accessed on 20 July 2019).

23. Wilson, D.; Jackson, T.; Sapey, E.; Lord, J.M. Frailty and sarcopenia: The potential role of an aged immune system. Ageing Res. Rev. 2017, 36, 1-10. [CrossRef] [PubMed]

24. Morley, J.E.; Vellas, B.; van Kan, G.A.; Anker, S.D.; Bauer, J.M.; Bernabei, R.; Cesari, M.; Chumlea, W.C.; Doehner, W.; Evans, J.; et al. Frailty Consensus: A call to action. J. Am. Med. Dir. Assoc. 2013, 14, 392-397. [CrossRef] 
25. Schiffman, S.; Graham, B. Taste and smell perception affect appetite and immunity in the elderly. Eur. J. Clin. Nutr. 2000, 54, 54-63. [CrossRef]

26. Morley, J. Workshop: Anorexia during disease-From research to clinical practice anorexia, sarcopenia and ageing. Nutrition 2001, 17, 660-663. [CrossRef]

27. Malafarina, V.; Uriz-Otano, F.; Gil-Guerrero, L.; Iniesta, R. The anorexia of ageing: Physiopathology, prevalence, associated comorbidity and mortality. A systematic review. Maturitas 2013, 74, 293-302. [CrossRef] [PubMed]

28. Vandenberghe-Descamps, M.; Sulmont-Rosse, C.; Septier, C.; Feron, G.; Laboure, H. Using food comfortability to compare foods sensory characteristics expectations of elderly people with or without oral health problems. J. Texture Stud. 2017, 48, 280-287. [CrossRef]

29. Gura, K.; Ciccone, R. Drugs and appetite. An overview of appetite stimulants in the paediatric patient. ICAN Infant Child Adolesc. Nutr. 2010, 2, 358-369. [CrossRef]

30. Nieuwenhuizen, W.F.; Weenen, H.; Rigby, P.; Hetherington, M.M. Older adults and patients in need of nutritional support: Review of current treatment options and factors influencing nutritional intake. Clin. Nutr. 2010, 29, 160-169. [CrossRef]

31. Stull, A.J.; Apolzan, J.W.; Thalacker-Mercer, A.E.; Iglay, H.; Campbell, W.W. Liquid and solid meal replacement products differentially affect postprandial appetite and food intake in older adults. J. Am. Diet. Assoc. 2008, 108, 1226-1230. [CrossRef]

32. Chambers, L. Food texture and the satiety cascade. Nutr. Bull. 2016, 41, 277-282. [CrossRef]

33. Giezenaar, C.; Chapman, I.; Luscombe-Marsh, N.; Feinle-Bisset, C.; Horowitz, M.; Soenen, S. Ageing is associated with decreases in appetite and energy intake-A meta analysis in healthy adults. Nutrients 2016, 8, 28. [CrossRef] [PubMed]

34. Razak, P.A.; Richard, K.M.J.; Thankachan, R.P.; Hafiz, K.A.A.; Kumar, K.N.; Sameer, K.M. Geriatric oral health: A review article. J. Int. Oral Health 2014, 6, 110-116.

35. Rathee, M.; Hooda, A. Nutritional status in denture wearers: A review. Int. J. Nutr. Wellness 2009, 10, 1-5.

36. Watson, S.; McGowan, L.; McCrum, L.A.; Cardwell, C.R.; McGuinness, B.; Moore, C.; Woodside, J.V.; McKenna, G. The impact of dental status on perceived ability to eat certain foods and nutrient intake in older adults: Cross-sectional analysis of the UK National Diet and Nutrient survey 2008-2014. Int. J. Behav. Nutr. Phys. Act. 2019, 16,1-13. [CrossRef] [PubMed]

37. Kremer, S.; Bult, J.H.F.; Mojet, J.; Kroeze, J.H.A. Food perception with age and its relationship to pleasantness. Chem. Senses 2007, 32, 591-602. [CrossRef] [PubMed]

38. Methven, L.; Jimenez-Pranteda, M.L.; Lawlor, J. Sensory and consumer science methods used with older adults: A review of current methods and recommendations for the future. Food Qual. Pref. 2016, 48, 333-344. [CrossRef]

39. Imoscopi, A.; Inelmen, E.M.; Sergi, G.; Miotto, F.; Manzato, E. Taste loss in the elderly: Epidemiology, causes and consequences. Aging Clin. Exp. Res. 2012, 24, 570-579.

40. Solemadal, K.; Sandvik, L.; Willumsen, T.; Mowe, M.; Hummel, T. The impact of oral health on taste ability in acutely hospitalized elderly. PLoS ONE 2012, 7, e36557. [CrossRef]

41. Moody, A.; Mindell, J.; Faulding, S. Health Survey for England 2016. 2017. Available online: http://healthsurvey.hscic.gov.uk/ media / 63790/HSE2016-pres-med.pdf (accessed on 7 January 2019).

42. Ciancio, S.G. Medications impact on oral health. J. Am. Dent. Assoc. 2004, 135, 1440-1448. [CrossRef]

43. Stratton, R.; Smith, T.; Gabe, S. Managing Malnutrition to Improve Lives and Save Money. 2018. Available online: https: //www.bapen.org.uk/pdfs/reports/mag/managing-malnutrition.pdf (accessed on 3 January 2019).

44. Hoffman, J.R.; Falvo, M.J. Protein-Which is best? J. Sci. Med. 2004, 3, 118-130.

45. Pires, M.A.; Pastrana, L.M.; Fucinos, P.; Abreu, C.S.; Oliveira, S.M. Sensorial Perception of Astringency: Oral Mechanisms and Current Analysis Methods. Foods 2020, 9, 1124. [CrossRef]

46. Carter, B.G.; Foegeding, E.A.; Drake, M.A. Invited review: Astringency in whey protein beverages. J. Dairy. Sci. 2020, 103, 5793-5804. [CrossRef]

47. Department of Health. 1991. Available online: https://assets.publishing.service.gov.uk/government/uploads/system/uploads/ attachment_data/file/743790/Dietary_Reference_Values_-_A_Guide_1991_.pdf (accessed on 4 January 2019).

48. Stevenson, E.J.; Watson, A.W.; Brunstrom, J.M.; Corfe, B.M.; Green, M.A.; Johnstone, A.M.; Williams, E.A. Protein for life: Towards a focused dietary framework for healthy ageing. Nutr. Bull. 2018, 43, 97-102. [CrossRef]

49. PENG. 2011. Available online: https:/ / www.peng.org.uk/publications-resources/pocket-guide.php (accessed on 10 January 2019).

50. Veldhorst, M.; Smeets, A.; Soenen, S.; Hochstenbach-Waelen, A.; Hursel, R.; Diepvens, K.; Lejeune, M.; Luscombe-Marsh, N.; Westerterp-Plantenga, M. Protein-induced satiety: Effects and mechanism of different proteins. Physiol. Behav. 2008, 94, 300-307. [CrossRef]

51. Giezenaar, C.; Trahair, L.G.; Rigda, R.; Hutchison, A.T.; Feinle-Bisset, C.; Luscombe-Marsh, N.D.; Hausken, T.; Jones, K.L. Lesser suppression of energy intake by orally ingested whey protein in healthy older men compared with young controls. Am. J. Physiol. Regul. Integr. Comp. Physiol. 2015, 309, 845-854. [CrossRef]

52. Giezenaar, C.; Trahair, L.G.; Luscombe-Marsh, N.D.; Hausken, T.; Standfield, S.; Jones, K.L.; Lange, K.; Horowitz, M.; Chapman, I.; Soenen, S. Effects of randomized whey-protein loads on energy intake, appetite, gastric emptying, and plasma gut hormone concentrations in older men and women. Am. J. Clin. Nutr. 2017, 106, 865-877. [CrossRef] [PubMed]

53. BAPEN. 2016. Available online: https://www.bapen.org.uk/nutrition-support/nutrition-by-mouth/oral-nutritionalsupplements (accessed on 8 January 2019). 
54. Wang, Z.; Chang, S.; Li, Y.; Kong, L.; Wu, D.; Qin, L.; Yu, C.; Wu, C.; Du, M. Effects of ball milling treatment on physiochemical properties and digestibility of Pacific oyster (Crassostrea gigas) protein powder. Food Sci. Nutr. 2018, 6, 1582-1590. [CrossRef] [PubMed]

55. Croissant, A.E.; Kang, E.J.; Campbell, R.E.; Bastian, E.; Drake, M.A. The effect of bleaching agent on the flavour of liquid whey and whey protein concentrate. J. Dairy Sci. 2009, 92, 5917-5927. [CrossRef]

56. Evans, J.; Zulewska, J.; Newbold, M.; Drake, M.A.; Barbano, D.M. Comparison of composition and sensory properties of 80\% whey protein and milk serum protein concentrates. J. Dairy Sci. 2010, 93, 1824-1843. [CrossRef] [PubMed]

57. Mills, S.R.; Wilcox, C.R.; Ibrahim, K.; Roberts, H.C. Can fortified foods and snacks increase the energy and protein intake of hospitalised older patients? A systematic review. J. Hum. Nutr. Diet. 2018, 31, 379-389. [CrossRef]

58. Morilla-Herrera, J.C.; Martin-Santos, F.J.; Caro-Bautista, J.; Saucedo-Figueredo, C.; Garcia-Mayor, S.; Morales-Asencio, J.M. Effectiveness of food based fortification in older people a systematic review and meta-analysis. J. Nutr. Health Aging 2016, 20, 178-184. [CrossRef]

59. Cawood, A.L.; Elia, M.; Stratton, R.J. Systematic review and meta analysis of the effects of high protein oral nutritional supplements. Ageing Res. Rev. 2012, 11, 278-296. [CrossRef] [PubMed]

60. Parsons, E.L.; Stratton, R.J.; Cawood, A.L.; Smith, T.R.; Elia, M. Oral nutritional supplements in a randomised trial are more effective than dietary advice at improving quality of life in malnourished care home residents. Clin. Nutr. 2017, 36, 134-142. [CrossRef] [PubMed]

61. Bauer, J.M.; Verlaan, S.; Bautmans, I.; Brandt, K.; Donini, L.M.; Maggio, M.; McMurdo, M.E.T.; Mets, T.; Seal, C.; Wijers, S.L.; et al. Effects of a vitamin D and leucine-enriched whey protein nutritional supplement on measures of sarcopenia in older adults, the PROVIDE study: A randomised, double blind, placebo controlled trial. J. Am. Med. Dir. Assoc. 2015, 16, 740-747. [CrossRef] [PubMed]

62. Munk, T.; Beck, A.M.; Holst, M.; Rosenbom, E.; Rasmussen, H.H.; Nielsen, M.A.; Thomsen, T. Positive effect of protein supplementation hospital food on protein intake in patients at nutritional risk: A randomised controlled trial. J. Hum. Nutr. Diet. 2014, 27, 122-132. [CrossRef] [PubMed]

63. Appleton, K.M.; Smith, E. A role for identification in the gradual decline in the pleasantness of flavours with age. J. Gerontol. Psychol. Sci. 2015, 71, 987-994. [CrossRef] [PubMed]

64. Beelen, J.; de Roos, N.M.; de Groot, L.C.P.G.M. Protein enrichment of familiar foods as an innovative strategy to increase protein intake in institutionalized elderly. J. Nutr. Health Aging 2017, 21, 173-179. [CrossRef] [PubMed]

65. Beelen, J.; de Roos, N.M.; de Groot, L.C.P.G.M. A 12 week intervention with protein enriched foods and drinks improved protein intake but not physical performance of older patients during the first 6 months after hospital release: A randomised controlled trial. Br. J. Nutr. 2017, 117, 1541-1549. [CrossRef]

66. Devries, M.C.; Sithamparapillai, A.; Brimble, K.S.; Banfield, L.; Morton, R.W.; Philips, S.M. Changes in kidney function do not differ between healthy adults consuming higher compared with lower or normal protein diets: A systematic review and meta analysis. J. Nutr. 2018, 148, 1760-1775. [CrossRef]

67. Mitchell, S.M.; McKenzie, E.J.; Mitchell, C.J.; Milan, A.M.; Zeng, N.; D’Souza, R.F.; Ramzan, F.; Sharma, P.; Rettedal, E.; Knowles, S.O.; et al. A period of 10 weeks of increased protein consumption does not alter faecal microbiota or volatile metabolites in healthy older men: A randomised controlled trial. J. Nutr. Sci. 2020, 9, 1-3. [CrossRef] [PubMed]

68. Stratton, R.J.; Elia, M. A review of reviews: A new look at the evidence for oral nutritional supplements in clinical practice. Clin. Nutr. Supp. 2007, 2, 5-23. [CrossRef]

69. Parker, A.M.; Watson, R.R. Lactose Intolerance. In Nutrients in Dairy and Their Implications on Health and Disease; Watson, R.R., Collier, R.J., Preedy, V.R., Eds.; Academic Press: New York, NY, USA, 2017; pp. 205-211.

70. Anema, S.G. The whey proteins in milk: Thermal denaturation, physical interactions, and effects on the functional properties of milk. In Milk Proteins: From Expression to Food, 2nd ed.; Boland, M., Singh, H., Thompson, Eds.; Academic Press: New York, NY, USA, 2014; pp. 270-311.

71. O'Mahony, J.A.; Fox, P.F. Milk: An overview. In Milk Proteins: From Expression to Food, 2nd ed.; Boland, M., Singh, H., Thompson, Eds.; Academic Press: New York, NY, USA, 2014; pp. 20-61.

72. Madureira, A.R.; Pereira, C.I.; Gomes, A.M.P.; Pintado, M.E.; Malcata, F.X. Bovine whey proteins-Overview on their main biological properties. Food Res. Int. 2007, 40, 1197-1211. [CrossRef]

73. Bansal, N.; Bhandari, B. Functional Milk Proteins: Production and Utilization-Whey Based Ingredients. In Advanced Dairy Chemistry. Volume 1B: Proteins: Applied Aspects, 4th ed.; McSweeney, P.L.H., O'Mahony, J.A., Eds.; Springer: New York, NY, USA, 2016; pp. 67-99.

74. Frankowski, K.M.; Miracle, R.E.; Drake, M.A. The role of sodium in the salty taste of permeate. J. Dairy Sci. 2014, 97, 5356-5370. [CrossRef] [PubMed]

75. Etzel, M.R. Manufacture and use of dairy protein fractions. J. Nutr. 2004, 134, 996S-1002S. [CrossRef]

76. Smithers, G.W. Whey and whey proteins-from 'gutter-to-gold'. Int. Dairy J. 2008, 18, 695-704. [CrossRef]

77. Dangin, M.; Guillet, C.; Garcia-Rodenas, C.; Gachon, P.; Bouteloup-Demange, C.; Reiffers-Magnani, K.; Fauquant, J.; Ballevre, O.; Beaufrere, B. The rate of protein digestion affects protein gain differently during ageing in humans. J. Physiol. 2003, 549, 635-644. [CrossRef] 
78. Sahathevan, S.; Se, C.H.; Ng, S.H.; Khor, B.H.; Chinna, K.; Goh, B.L.; Gafor, H.A.; Bavanandan, S.; Ahmad, G.; Karupaiah, T. Clinical efficacy and feasibility of whey protein isolates supplementation in malnourished peritoneal dialysis patients: A multicentre, parallel, open-label randomised controlled trial. Clin. Nutr. ESPEN 2018, 25, 68-77. [CrossRef]

79. Pennings, B.; Boirie, Y.; Senden, J.M.; Gijsen, A.P.; Kuipers, H.; van Loon, L.J. Whey protein stimulates postprandial muscle protein accretion more effectively than do casein and casein hydrolysate in older men. Am. J. Clin. Nutr. 2011, 93, 997-1005. [CrossRef] [PubMed]

80. Solak, B.B.; Akin, N. Health benefits of whey protein: A review. J. Food Sci. Eng. 2012, 2, 129-137.

81. Gosney, M. Are we wasting our money on food supplements in elder care wards? J. Adv. Nurs. 2003, 43, 275-280. [CrossRef]

82. Hubbard, G.P.; Elia, M.; Holdoway, A.; Stratton, R.J. A systematic review of compliance to oral nutritional supplements. Clin. Nutr. 2012, 31, 293-312. [CrossRef] [PubMed]

83. Childs, J.L.; Drake, M.A. Consumer perception of astringency in clear acidic whey protein beverages. J. Food Sci. 2010, 75, 513-521. [CrossRef] [PubMed]

84. Kennedy, O.; Law, C.; Methven, L.; Mottram, D.; Gosney, M. Investigating age related changes in taste and affects on sensory perceptions of oral nutritional supplements. Age Ageing 2010, 39, 733-738. [CrossRef] [PubMed]

85. Methven, L.; Rahelu, K.; Economou, N.; Kinneavy, L.; Ladbrooke-Davis, L.; Kennedy, O.B.; Mottram, D.S.; Gosney, M.A. The effect of consumption volume of profile and liking of oral nutritional supplements of varied sweetness: Sequential profiling and boredom tests. Food Qual. Prefer. 2010, 21, 948-955. [CrossRef]

86. Bull, S.P.; Hong, Y.; Khutoryanskiy, V.V.; Parker, J.K.; Faka, M.; Methven, L. Whey protein mouth drying influenced by thermal denaturation. Food Qual. Prefer. 2017, 56, 233-240. [CrossRef]

87. Thomas, A.; van der Stelt, A.J.; Prokop, J.; Lawlor, J.B.; Schlich, P. Alternating temporal dominance of sensations and liking scales during the intake of a full portion of an oral nutritional supplement. Food Qual. Prefer 2016, 53, 159-167. [CrossRef]

88. Thomas, A.; van der Stelt, A.J.; Schlich, P.; Lawlor, J.B. Temporal drivers of liking for oral nutritional supplements for older adults throughout the day with monitoring of hunger and thirst status. Food Qual. Prefer. 2018, 70, 40-48. [CrossRef]

89. Norton, V.; Lignou, S.; Bull, S.P.; Gosney, M.A.; Methven, L. An investigation of the influence of age and saliva flow on the oral retention of whey protein and its potential effect on the perception and acceptance of whey protein beverages. Nutrients 2020, 12, 2506. [CrossRef] [PubMed]

90. Norton, V.; Lignou, S.; Bull, S.P.; Gosney, M.A.; Methven, L. Consistent effects of whey protein fortification on consumer perception and liking of solid food matrices (cakes and biscuits) regardless of age and saliva flow. Foods 2020, 9, 1328. [CrossRef]

91. Oltman, A.E.; Lopetcharat, K.; Bastian, E.; Drake, M.A. Identifying key attributes for protein beverages. J. Food Sci. 2015, 80, S1383-S1390. [CrossRef] [PubMed]

92. Zhang, M.T.; Jo, Y.; Lopetcharat, K.; Drake, M.A. Comparison of a central location test versus a home usage test for consumer perception of ready-to-mix protein beverages. J. Dairy Sci. 2020, 103, 3107-3124. [CrossRef] [PubMed]

93. Wendin, K.; Hoglund, E.; Andersson, M.; Rothenberg, E. Protein enriched foods and healthy ageing: Effects of protein fortification on muffin characteristics. Agro Food Ind. Hi-Tech 2017, 28, 16-18.

94. Song, X.; Perez-Cueto, F.J.A.; Bredie, W.L. Sensory-driven development of protein-enriched rye bread and cream cheese for the nutritional demands of older adults. Nutrients 2018, 10, 1006. [CrossRef]

95. Whetstine, M.E.; Croissant, A.E.; Drake, M.A. Characterization of dried whey protein concentrate and isolate flavour. J. Dairy Sci. 2005, 88, 3826-3839. [CrossRef]

96. Karagul-Yuceer, Y.; Drake, M.A.; Cadwallader, K.R. Aroma-active components of liquid cheddar whey. J. Food Chem. Toxicol. 2003, 68, 1215-1219. [CrossRef]

97. Wright, J.M.; Whetstine, M.E.C.; Miracle, R.E.; Drake, M.A. Characterization of a cabbage off flavour in whey protein isolate. J. Food Sci. 2006, 71, 86-90. [CrossRef]

98. Russell, T.A.; Drake, M.A.; Gerard, P.D. Sensory properties of whey and soy proteins. J. Food Sci. 2006, 71, S447-S455. [CrossRef]

99. Tsikritzi, R.; Wang, J.; Collins, V.J.; Allen, V.J.; Mavrommatis, Y.; Moynihan, P.J.; Gosney, M.A.; Kennedy, O.B.; Methven, L. The effect of nutrient fortification of sauces on product stability, sensory properties, and subsequent liking by older adults. J. Food Sci. 2015, 80, 1100-1110. [CrossRef]

100. Tsikritzi, R.; Moynihan, P.J.; Gosney, M.A.; Allen, V.J.; Methven, L. The effect of macro- and micro-nutrient fortification of biscuits on their sensory properties and on hedonic liking of older people. J. Sci. Food Agric. 2014, 94, 2040-2048. [CrossRef]

101. Vandenberghe-Descamps, M.; Laboure, H.; Prot, A.; Septier, C.; Tournier, C.; Feron, G.; Sulmont-Rosse, C. Salivary flow decreases in healthy elderly people independently of dental status and drug intake. J. Texture Stud. 2016, 47, 353-360. [CrossRef]

102. Thomson, W.M. Dry mouth and older people. Aust. Dent. J. 2015, 60, 54-63. [CrossRef]

103. Guinard, J.X.; Mazzucchelli, R. The sensory perception of texture and mouthfeel. Trends Food Sci. Technol. 1996, 7, $213-219$. [CrossRef]

104. Szczesniak, A.S. Texture is a sensory property. Food Qual. Prefer. 2002, 13, 215-225. [CrossRef]

105. Szczesniak, A.S.; Kahn, E.L. Consumer awareness of and attitudes to food texture I: Adults. J. Texture Stud. $1971,2,280-295$. [CrossRef]

106. Lemieux, L.; Simard, R.E. Astringency, a textural defect in dairy products. Lait 1994, 74, 217-240. [CrossRef]

107. ASTM E253-20. Available online: http:/ / www.astm.org/cgi-bin/resolver.cgi?E253 (accessed on 1 July 2020).

108. Green, B.G. Oral astringency: A tactile component of flavor. Acta Psychol. 1993, 84, 119-125. [CrossRef] 
109. Breslin, P.A.S.; Gilmore, M.M.; Beauchamp, G.K.; Green, B.G. Psychophysical evidence that oral astringency is a tactile sensation. Chem. Senses 1993, 18, 405-417. [CrossRef]

110. Gibbins, H.L.; Carpenter, G.H. Alternative mechanisms of astringency-what is the role of saliva? J. Texture Stud. 2013, 44, 364-375. [CrossRef]

111. Bajec, M.R.; Pickering, G.J. Astringency: Mechanisms and perception. Crit. Rev. Food Sci. Nutr. 2008, 48, 858-875. [CrossRef]

112. Damodaran, S.; Arora, A. Off flavour precursors in soy protein isolate and novel strategies for their removal. Annu. Rev. Food Sci. Technol. 2013, 4, 327-346. [CrossRef]

113. Cosson, A.; Souchon, I.; Richard, J.; Descamps, N.; Saint-Eve, A. Using Multiple Sensory Profiling Methods to Gain Insight into Temporal Perceptions of Pea Protein-Based Formulated Foods. Foods 2020, 9, 969. [CrossRef]

114. Jobstl, E.; O'Connell, J.; Fairclough, P.A.; Williamson, M.P. Molecular model for astringency produced by polyphenol/protein interactions. Biomacromolecules 2004, 5, 942-949. [CrossRef] [PubMed]

115. Lyman, B.J.; Green, B.G. Oral astringency: Effects of repeated exposure and interactions with sweeteners. Chem. Senses 1990, 15, 151-164. [CrossRef]

116. Thorngate, J.H.; Noble, A.C. Sensory evaluation of bitterness and astringency of 3R(-)-Epicatechin and 3S(+)-Catechin. J. Sci. Food Agric. 1995, 67, 531-535. [CrossRef]

117. Linne, B.; Simons, C.T. Quantification of oral roughness perception and comparison with mechanism of astringency perception. Chem. Senses 2017, 42, 525-536. [CrossRef] [PubMed]

118. Bajec, M.R.; Pickering, G.J. Thermal taste, PROP responsiveness, and perception of oral sensations. Physiol. Behav. 2008, 95, 581-590. [CrossRef]

119. Dinnella, C.; Recchia, A.; Tuorila, H.; Monteleone, E. Individual astringency responsiveness affects the acceptance of phenol-rich foods. Appetite 2011, 56, 633-642. [CrossRef] [PubMed]

120. Fleming, E.E.; Ziegler, G.R.; Hayes, J.E. Salivary protein levels as a predictor of perceived astringency in model systems and solid foods. Physiol. Behav. 2016, 163, 56-63. [CrossRef]

121. Schöbel, N.; Radtke, D.; Kyereme, J.; Wollmann, N.; Cichy, A.; Obst, K.; Kallweit, K.; Olaf Kletke, O.; Minovi, A.; Dazert, S.; et al. Astringency Is a Trigeminal Sensation That Involves the Activation of G Protein-Coupled Signaling by Phenolic Compounds. Chem. Senses 2014, 39, 471-487. [CrossRef] [PubMed]

122. Withers, C.A.; Lewis, M.J.; Gosney, M.A.; Methven, L. Potential sources of mouth drying in beverages fortified with dairy proteins: A comparison of casein- and whey-rich ingredients. J. Dairy Sci. 2014, 97, 1233-1247. [CrossRef]

123. Kelly, M.; Vardhanabhuti, B.; Luck, P.; Drake, M.A.; Osborne, J.; Foegeding, E.A. Role of protein concentration and protein-saliva interactions in the astringency of whey proteins at low pH. J. Dairy Sci. 2010, 93, 1900-1909. [CrossRef] [PubMed]

124. Beecher, J.W.; Drake, M.A.; Luck, P.J.; Foegeding, E.A. Factors regulating astringency of whey protein beverages. J. Dairy Sci. 2008, 91, 2553-2560. [CrossRef]

125. Vardhanabhuti, B.; Kelly, M.A.; Luck, P.J.; Drake, M.A.; Foegeding, E.A. Roles of charge interactions on astringency of whey proteins at low pH. J. Dairy Sci. 2010, 93, 1890-1899. [CrossRef] [PubMed]

126. Ye, A.; Streicher, C.; Singh, H. Interactions between whey proteins and salivary proteins as related to astringency of whey protein beverages at low pH. J. Dairy Sci. 2011, 94, 5842-5850. [CrossRef]

127. Andrewes, P.; Kelly, M.; Vardhanabhuti, B.; Foegeding, E.A. Dynamic modelling of whey protein-saliva interactions in the mouth and relation to astringency in acidic beverages. Int. Dairy J. 2011, 21, 523-530. [CrossRef]

128. Vardhanabhuti, B.; Cox, P.W.; Norton, I.T.; Foegeding, E.A. Lubricating properties of human whole saliva as affected by beta-lactoglobulin. Food Hydrocoll. 2011, 25, 1499-1506. [CrossRef]

129. Wang, G.; Liu, N.; Guo, M. Use of whey protein as a natural polymer for tissue adhesive: Preliminary formulation and evaluation in vitro. Polymers 2018, 10, 843. [CrossRef]

130. Hsein, H.; Garrait, G.; Beyssac, E.; Hoffart, V. Whey protein mucoadhesive properties for oral drug delivery: Mucin whey protein interaction and mucoadhesive bond strength. Coll. Surf. B 2015, 136, 799-808. [CrossRef] [PubMed]

131. Withers, C.A.; Cook, M.T.; Methven, L.; Gosney, M.A.; Khutoryanskiy, V.V. Investigation of milk proteins binding to the oral mucosa. Food Funct. 2013, 4, 1668-1674. [CrossRef] [PubMed]

132. Wijayanti, H.B.; Bansal, N.; Deeth, H.C. Stability of whey proteins during thermal processing: A review. Compr. Rev. Food Sci. Food Saf. 2014, 13, 1235-1251. [CrossRef]

133. Josephson, R.V.; Thomas, E.L.; Morr, C.V.; Coulter, S.T. Relation of heat-induced changes in protein-salt constituents to astringency in milk systems. J. Dairy Sci. 1967, 50, 1376-1383. [CrossRef]

134. Bull, S.P.; Khutoryanskiy, V.V.; Parker, J.K.; Faka, M.; Methven, L. Oral retention of whey protein: Measurement and mechanisms. Food Chem. 2020. submitted for publication.

135. Çelebioğlu, H.Y.; Lee, S.; Chronakis, I.S. Interactions of salivary mucins and saliva with food proteins: A review. Crit. Rev. Food Sci. Nutr. 2020, 60, 64-83. [CrossRef]

136. Cook, S.L.; Woods, S.; Methven, L.; Parker, J.K.; Khutoryanskiy, V.V. Mucoadhesive polysaccharides modulate sodium retention, release and taste perception. Food Chem. 2018, 240, 482-489. [CrossRef]

137. Lucas, P.W.; Prinz, J.F.; Agrawal, K.R.; Bruce, I.C. Food texture and its effect on ingestion, mastication and swallowing. J. Texture Stud. 2004, 35, 159-170. [CrossRef] 
138. Cook, S.L.; Bull, S.P.; Methven, L.; Parker, J.K.; Khutoryanskiy, V.V. Mucoadhesion: A food perspective. Food Hydrocoll. 2017, 72, 281-296. [CrossRef]

139. Sano, H.; Egashira, T.; Kinekawa, Y.; Kitabatake, N. Astringency of bovine milk whey protein. J. Dairy Sci. 2005, 88, 2312-2317. [CrossRef]

140. Ye, A.; Zheng, T.; Ye, J.Z.; Singh, H. Potential role of the binding of whey proteins to human buccal cells on the perception of astringency in whey proteins beverages. Physiol. Behav. 2012, 106, 645-650. [CrossRef] [PubMed]

141. Wang, T.; Tan, S.Y.; Mutilangi, W.; Plans, M.; Rodriguez-Saona, L. Application of infrared portable sensor technology for predicting perceived astringency of acidic whey protein beverages. J. Dairy Sci. 2016, 99, 9461-9470. [CrossRef] [PubMed]

142. Lee, C.A.; Vickers, Z.M. The astringency of whey protein beverages is caused by their acidity. Int. Dairy J. 2008, 18, 1153-1156. [CrossRef]

143. Withers, C.; Gosney, M.A.; Methven, L. Perception of thickness, mouth coating and mouth drying of dairy beverages by younger and older volunteers. J. Sens. Stud. 2013, 28, 230-237. [CrossRef]

144. Smart, J.D. The basics and underlying mechanisms of mucoadhesion. Adv. Drug Deliv. Rev. 2005, 57, 1556-1568. [CrossRef]

145. Andrews, G.P.; Laverty, T.P.; Jones, D.S. Mucoadhesive polymeric platforms for controlled drug delivery. Eur. J. Pharm. Biopharm. 2009, 71, 505-518. [CrossRef] [PubMed]

146. Carvalho, F.C.; Bruschi, M.L.; Evangelista, R.C.; Gremiao, M.P.D. Mucoadhesive drug delivery systems. Braz. J. Pharm. Sci. 2010, 46, 1-17. [CrossRef]

147. Khutoryanskiy, V.V. Advances in mucoadhesion and mucoadhesive polymers. Macromol. Biosci. 2011, 11, 748-764. [CrossRef]

148. Bassi da Silva, J.; Ferreira, S.B.S.; Reis, A.V.; Cook, M.T.; Bruschi, M.L. Assessing mucoadhesion in polymer gels: The effect of method type and instrument variables. Polymers 2018, 10, 254. [CrossRef] [PubMed]

149. Bernkop-Schnurch, A. Thiomers: A new generation of mucoadhesive polymers. Adv. Drug Deliv. Rev. 2005, 57, 1569-1582. [CrossRef]

150. Tortora, G.J.; Nielsen, M.T. Principles of Human Anatomy, 11th ed.; John Wiley \& Sons, Inc: Hoboken, NJ, USA, 2009.

151. Wickremaratchi, M.M.; Llewelyn, J.G. Effects of ageing on touch. Postgrad. Med. J. 2006, 82, 301-304. [CrossRef]

152. Methven, L.; Allen, V.; Withers, C.; Gosney, M.A. Ageing and Taste. Proc. Nutr. Soc. 2012, 71, 556-565. [CrossRef]

153. Doty, R.L.; Kamath, V. The influence of age on olfaction: A review. Front Psychol. 2014, 5, 1-20. [CrossRef]

154. Schiffman, S.S.; Zervakis, J. Taste and smell perception in the elderly: Effect of medications and disease. Adv. Food Nutr. Res. 2002, $44,248-345$.

155. Kremer, S.; Mojet, J.; Kroeze, J.H.A. Perception of texture and flavor in soups by elderly and young subjects. J. Texture Stud. 2005, 36, 255-272. [CrossRef]

156. Kremer, S.; Mojet, J.; Kroeze, J.H.A. Differences in perception of sweet and savoury waffles between elderly and young subjects. Food Qual. Prefer. 2007, 38, 106-116. [CrossRef]

157. Hutchings, S.C.; Foster, K.D.; Grigor, J.M.V.; Bronlund, J.E.; Morgenstern, M.P. Temporal dominance of sensations: A comparison between younger and older subjects for the perception of food texture. Food Qual. Prefer. 2014, 31, 106-115. [CrossRef]

158. Forde, C.G.; Delahunty, C.M. Understanding the role cross-modal sensory interactions play in food acceptability in younger and older consumers. Food Qual. Prefer. 2004, 15, 715-727. [CrossRef]

159. Engelen, L. Oral processing: Implications for consumer choice and preference. In Methods in Consumer Research, Volume 1: New Approaches to Classic Methods; Ares, G., Varela, P., Eds.; Woodhead Publishing: Cambridge, UK, 2018; pp. 401-421.

160. Engelen, L.; Van Der Bilt, A. Oral physiology and texture perception of semisolids. J. Texture Stud. 2008, 39, 83-113. [CrossRef]

161. Laureati, M.; Sandvik, P.; Almli, V.L.; Sandell, A.M.; Zeinstra, G.G.; Methven, L.; Wallner, M.; Jilani, H.; Alfaro, B.; Proserpio, C. Individual differences in texture preferences among European children: Development and validation of child food texture preference questionnaire (CFTPQ). Food Qual. Prefer. 2020, 80, 103828. [CrossRef]

162. Ketal, E.V.; Aguayo-Mendoza, M.G.; de Wijk, R.A.; de Graaf, C.; Piqueras-Fiszman, B.; Stieger, M. Age, gender, ethnicity and eating capability influence oral processing behaviour of liquid, semi-solid and solid foods differently. Food Res. Int. 2019, 119, 143-151. [CrossRef]

163. Ketal, E.V.; de Wijk, R.A.; de Graaf, C.; Stieger, M. Relating oral physiology and anatomy of consumers varying in age, gender and ethnicity to food oral processing behavior. Physiol. Behav. 2020, 215, 112766. [CrossRef] [PubMed]

164. van den Heuvel, E.; Newbury, A.; Appleton, K.M. The psychology of nutrition with advancing age: Focus on food neophobia. Nutrients 2019, 11, 151. [CrossRef]

165. Jeltema, M.; Beckley, J.; Vahalik, J. Model for understanding consumer textural food choice. Food Sci. Nutr. 2015, 3, $202-212$. [CrossRef]

166. Jeltema, M.; Beckley, J.; Vahalik, J. Food texture assessment and preference based on mouth behavior. Food Qual. Prefer. 2016, 52, 160-171. [CrossRef]

167. Pereira, L.J. Oral cavity. In Food Oral Processing: Fundamentals of Eating and Sensory Perception, 1st ed.; Chen, J., Engelen, L., Eds.; Wiley-Blackwell: Hoboken, NJ, USA, 2012; pp. 139-156.

168. Hand, A.R.; Frank, M.E. Fundamentals of Oral Histology and Physiology; Wiley Blackwell: Hoboken, NJ, USA, 2014.

169. Engelen, L. Oral Receptors. In Food Oral Processing: Fundamentals of Eating and Sensory Perception, 1st ed.; Chen, J., Engelen, L., Eds.; Wiley-Blackwell: Hoboken, NJ, USA, 2012; pp. 15-45.

170. Chen, J. Food oral processing-A review. Food Hydrocoll. 2009, 23, 1-25. [CrossRef] 
171. Stokes, J.R.; Boehm, M.W.; Baier, S.K. Oral processing, texture and mouthfeel: From rheology to tribology and beyond. Curr. Opin. Colloid Interface Sci. 2013, 18, 349-359. [CrossRef]

172. de Wijk, R.A.; Prinz, J.F. Mechanisms underlying the role of friction in oral texture. J. Texture Stud. 2006, 37, 413-427. [CrossRef]

173. Krop, E.M.; Hetherington, M.M.; Miquel, S.; Sarkar, A. The influence of oral lubrication on food intake: A proof-of-concept study. Food Qual. Prefe.r 2019, 74, 118-124. [CrossRef]

174. Mioche, L.; Bourdiol, P.; Monier, S.; Martin, J.F.; Cormier, D. Changes in jaw muscles activity with age: Effects on food bolus properties. Physiol. Behav. 2004, 82, 621-627. [CrossRef] [PubMed]

175. Crow, H.C.; Ship, J.A. Tongue strength and endurance in different aged individuals. J. Gerontol. Med. Sci. 1996, 51, M247-M250. [CrossRef] [PubMed]

176. Health and Social Care Information Centre. 2011. Available online: https://digital.nhs.uk/data-and-information/publications/ statistical/adult-dental-health-survey/adult-dental-health-survey-2009-summary-report-and-thematic-series (accessed on 12 January 2019).

177. Ikebe, K.; Matsuda, K.; Kagawa, R.; Enoki, K.; Yoshida, M.; Maeda, Y.; Nokubi, T. Association of masticatory performance with age, gender, number of teeth, occlusal force and salivary flow in Japanease older adults: Is ageing a risk factor for masticatory dysfunction? Arch. Oral Biol. 2011, 56, 991-996. [CrossRef] [PubMed]

178. Steele, J.G.; Ayatollahi, S.M.T.; Walls, A.W.G.; Murray, J.J. Clinical factors related to reported satisfaction with oral function amongst dentate older adults in England. Community Dent. Oral Epidemiol. 1997, 25, 143-149. [CrossRef] [PubMed]

179. Wilson, A.; Jeltema, M.; Morgenstern, M.P.; Motoi, L.; Kim, E.; Hedderley, D. Comparison of physical chewing measures to consumer typed mouthbehaviour. J. Texture Stud. 2018, 49, 262-273. [CrossRef]

180. Mioche, L.; Bourdiol, P.; Peyron, M. Influence of age on mastication: Effects on eating behaviour. Nutr. Res. Rev. 2004, 17, 43-54. [CrossRef]

181. Shinkawa, T.; Hayashida, N.; Mori, K.; Washio, K.; Hashiguchi, K.; Taira, Y.; Morishita, M.; Takamura, N. Poor chewing ability is associated with lower mucosal moisture in elderly individuals. Tohoku J. Exp. Med. 2009, 219, 263-267. [CrossRef]

182. Carpenter, G.H. The secretion, components, and properties of saliva. Annu. Rev. Food Sci. Technol. 2013, 4, 267-276. [CrossRef] [PubMed]

183. de Almeida, P.; Gregio, A.M.; Machado, M.A.; de Lima, A.A.; Azevedo, L.R. Saliva composition and functions: A comprehensive review. J. Contemp. Dent. Prac. 2008, 9, 72-80.

184. Humphrey, S.P.; Williamson, R.T. A review of saliva: Normal composition, flow, and function. J. Prosthet. Dent. 2001, 85, 162-169. [CrossRef]

185. Gupta, A.; Epstein, J.B.; Sroussi, H. Hyposalivation in elderly patients. J. Can. Dent. Assoc. 2006, 72, 841-846.

186. May, A.J.; Chatzeli, L.; Proctor, G.B.; Tucker, A.S. Salivary gland dysplasia in Fgf10 heterozygous mouse model of xerostomia. Curr. Mol. Med. 2015, 15, 674-682. [CrossRef] [PubMed]

187. Marton, K.; Madlena, M.; Banoczy, J.; Varga, G.; Fejerdy, P.; Sreebny, L.M.; Nagy, G. Unstimulated whole saliva flow rate in relation to sicca symptoms in Hungary. Oral Dis. 2008, 14, 472-477. [CrossRef]

188. Munoz-Gonzalez, C.; Vandenberghe-Descamps, M.; Feron, G.; Canon, F.; Laboure, H.; Sulmont-Rosse, C. Association between salivary hypofunction and food consumption in the elderlies. A systematic literature review. J. Nutr. Health Aging 2018, 22, 407-419. [CrossRef] [PubMed]

189. Xu, F.; Laguna, L.; Sarkar, A. Ageing-related changes in quantity and quality of saliva: Where do we stand in our understanding? J. Texture Stud. 2019, 50, 27-35. [CrossRef]

190. Affoo, R.H.; Foley, N.; Garrick, R.; Siqueira, W.L.; Martin, R.E. Meta-analysis of salivary flow rates in young and older adults. J. Am. Geriatr. Soc. 2015, 63, 2142-2151. [CrossRef] [PubMed]

191. Whelton, H. Introduction: The anatomy and physiology of salivary glands. In Saliva and Oral Health: An Essential Overview for the Health Professional, 4th ed.; Edgar, M., Dawes, C., O'Mullane, D., Eds.; Stephen Hancocks Limited: Oxford, UK, 2012 ; pp. 1-36.

192. Lee, S.K.; Lee, S.W.; Chung, S.C.; Kim, Y.K.; Kho, H.S. Analysis of residual saliva and minor salivary gland secretions in patients with dry mouth. Arch. Oral Biol. 2002, 47, 637-641. [CrossRef]

193. Turner, M.D.; Ship, J.A. Dry mouth and its effects on the oral health of elderly people. J. Am. Dent. Assoc. 2007, 138, 15-20. [CrossRef]

194. Chaudhury, N.M.A.; Shirlaw, P.; Pramanik, R.; Carpenter, G.H.; Proctor, G.B. Changes in saliva rheological properties and mucin glycosylation in dry mouth. J. Dent. Res. 2015, 94, 1660-1667. [CrossRef]

195. Nagler, R.M.; Hershkovich, O. Relationships between age, drugs, oral sensorial complaints and salivary profile. Arch. Oral Biol. 2005, 50, 7-16. [CrossRef]

196. Mosca, A.C.; Chen, J. Food-saliva interactions: Mechanisms and implications. Trends Food Sci. Technol. 2017, 66, 125-134. [CrossRef]

197. Munoz-Gonzalez, C.; Feron, G.; Canon, F. Main effects of human saliva on flavour perception and the potential contribution to food consumption. Proc. Nutr. Soc. 2018, 77, 423-431. [CrossRef]

198. Chen, J. Bolus formation and swallowing. In Food Oral Processing: Fundamentals of Eating and Sensory Perception, 1st ed.; Chen, J., Engelen, L., Eds.; Wiley-Blackwell: Hoboken, NJ, USA, 2012; pp. 139-156.

199. Feron, G. Unstimulated saliva: Background noise in taste molecules. J. Texture Stud. 2019, 50, 6-18. [CrossRef] 
200. Vijay, A.; Inui, T.; Dodds, M.; Proctor, G.; Carpenter, G. Factors that influence the extensional rheological property of saliva. PLoS ONE 2015, 10, e0135792. [CrossRef] [PubMed]

201. Pushpass, R.A.G.; Daly, B.; Kelly, C.; Proctor, G.; Carpenter, G.H. Altered salivary flow, protein composition, and rheology following taste and TRP stimulation in older adults. Front. Physiol. 2019, 10, 1-11. [CrossRef] [PubMed]

202. Munoz-Gonzalez, C.; Brule, M.; Feron, G.; Canon, F. Does interindividual variability of saliva affect the release and metabolization of aroma compounds ex vivo? The particular case of elderly suffering or not from hyposalivation. J. Texture Stud. 2019, 50, 36-44. [CrossRef] [PubMed] 